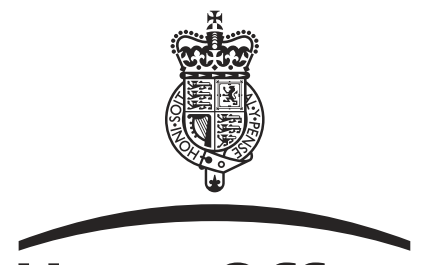

Care Services Improvement Partnership CSIP

Mental Health in England

(DH) Department
of Health

Home Office

\title{
Tackling the Health and Mental Health Effects of Domestic and Sexual Violence and Abuse
}

\author{
Professor Catherine Itzin
}

January 2006 



\section{Tackling the Health and Mental Health Effects of Domestic and Sexual Violence and Abuse}

\section{Professor Catherine Itzin}

Joint Department of Health and National Institute for Mental Health in England (NIMHE)

Victims of Violence and Abuse Prevention Programme (VVAPP) Health and Mental Health

Programme Implementation Guide In Partnership with the Home Office 



\section{Contents}

$\begin{array}{ll}\text { Ministerial Foreword } & 00\end{array}$

$\begin{array}{ll}\text { Executive Summary } & 00\end{array}$

Scope of the Programme 00

$\begin{array}{ll}\text { The Evidence Base } & 00\end{array}$

$\begin{array}{ll}\text { The Government Policy Context } & 00\end{array}$

The Purpose of the Programme 00

What the Programme Will Do 00

The Role of the Royal Colleges and Professional Bodies 00

The Role of the Violence and Abuse Voluntary and Independent Sector $\quad 00$

$\begin{array}{ll}\text { The Role of the Criminal Justice System } & 00\end{array}$

$\begin{array}{ll}\text { Focus on Prevention } & 00\end{array}$

Partnership Working at National and Local Level 00

Improving Outcomes for:

- Victims, Survivors and Service Users (including Abusers) 00

- Individuals in Black and Minority Ethnic Communities 00

- Individuals with Physical and Learning Disabilities 00

A Whole System Approach to Supporting Improvements in

Outcomes for Individuals and Organisations

Conclusion

00

- Programme Deliverables

- Stakeholder Participation 
Annex A - Programme Team and Expert Advisers

Annex B - A Whole System Strategic Framework

Annex C - VVAPP Programme Deliverables

00

References

00 


\section{Ministerial Foreword}

Domestic violence, rape and sexual assault, sexual exploitation and childhood physical, emotional and sexual abuse can have devastating lifelong effects on the health and mental health of its victims. That is why we are working together now across Government through the Inter- Departmental Ministerial Groups on Domestic Violence and Sexual Offending to address these issues.

Much has been achieved. Important new legislation has come into force: the Sexual Offences Act (2003) in May 2004, the Domestic Violence Crime and Victims ct (2004), and the Adoption and Children Act 2002 (for children harmed by domestic violence).

The Department of Health has established a wide-ranging policy context for addressing these issues through the Mental Health National Service Framework (1999), the Women's Mental Health Strategy (2002-3), the NSF for Children, Young People and Maternity Services (2004), and the Public Health White Paper Choosing Health (2004-5)

The Home Office has dedicated teams to support action on domestic violence, adolescent sexual abusers, adult victims of rape and sexual assault and adults sexually abused in childhood in the context of its domestic violence policy Safety and Justice (2003) and the National Victims and Witnesses Strategy (2004).

We therefore welcome the work of this programme which aims to improve the mental and physical well-being and quality of life of those who have been victimised. We are pleased that it involves the Department of Health, the Home Office and the National Institute for Mental Health in England (NIMHE) working in partnership.

All concerned are working with the violence and abuse voluntary sector which provides the majority of specialist services for victims of domestic and sexual violence and abuse, and represents the interests and the voice - of victims and survivors. 
By bringing together and building on the work of experts from across the relevant voluntary, statutory, academic, professional and criminal justice sectors this programme should bring about increased awareness, better understanding, and improvements in the treatment, care and support of the many individuals who are affected.

Most important must be a willingness to listen to victims and survivors, to acknowledge their experiences and to give them a sense of hope and recovery, and with abusers to focus on the prevention of new and continued offending.

Minister of State for Health Rosie Winterton MP

Baroness Scotland Home Office Minister
Parliamentary Secretary for Public Health

Caroline Flint MP

Paul Goggins MP Home Office Minister 


\section{Executive Summary}

1. This document outlines the two year programme of work currently being undertaken jointly by the Department of Health and National Institute for Mental Health in England (NIMHE) in partnership with the Home Office. The aim of the programme is to tackle the root causes of mental and physical ill health in child abuse and domestic and sexual violence as set out in the Public Health White Paper's cross government strategy (see Box 1) and in the PHWP Delivery Plan (see Box 2).

Box1: Choosing Health - Making healthy choices easier (Public Health White Paper 2004)

\section{Cross-government strategy for tackling the root causes of physical and mental ill health in child abuse and domestic violence}

Child physical, emotional or sexual abuse and neglect and domestic violence are causal factors in the mental and physical ill health of children, adolescents and adults and affect a significant proportion throughout their lives. The high costs in prevalence and economic burden on health and social care services and the criminal justice system have pushed these issues up the agenda.

They figure prominently in DH's policy on mental health, child health and women's health, and in wider government policy on child poverty, victims and witnesses, social exclusion and safeguarding children. They are also the focus of some crossgovernment working with DfES and the Home Office through the Inter-ministerial Groups on Domestic Violence and Sexual Offending in the wider context of new legislation on domestic violence, sexual offences and mental health.

1 Itzin, C (2000) Home Truths About Child Sexual Abuse, London, Routledge

2 Richardson, J. et al (2002) Identifying domestic violence: cross sectional study in primary care. BMJ 324(2) 274-27 
Box 2: Delivering Choosing Health: Making healthier choices easier (2005)

\section{Priority D: Improving sexual health}

- $\quad$ Sexual Assault Referral Centres (SARCs) - joint DH and HO initiative to develop nationally, including services for children and adolescents.

\section{Priority E: Improving mental health and well being}

- $\quad$ Targeted action to improve the quality of patient experience for example patients from black and minority ethnic communities or victims of domestic violence (such as through the joint $\mathrm{DH}, \mathrm{HO}$ and NIMHE violence and abuse programme).

2. The VVAPP programme was announced by Minister of State for Health Services Rosie Winterton MP in April 2004 at the Home Office National Victims Conference. Subsequently it has been the subject of Ministerial speeches at the National Domestic Violence Conference in October 2004 organised by Women's Aid with the Department of Health, and at the National Sexual Violence Conference in November 2005 - organised by the Home Office, Department of Health, Crown Prosecution Service and Association of Chief Police Officers.

3. Home Office Ministers Baroness Scotland and Paul Goggins have welcomed these initiatives and the opportunity they provide to work in partnership with the Home Office in the wider Government context of the Inter-Departmental Ministerial Groups on Domestic Violence and Sexual Offending.

4. The Victims of Violence \& Abuse Prevention Programme (VVAPP) has been established in response to the high prevalence of domestic and sexual violence and abuse and the evidence of mental and physical ill health associated with this. It builds on the literature on the 
nature, extent and effects of child sexual abuse, domestic violence, rape and sexual assault and sexual exploitation, and its co-occurrence across these groups. Much of this is based on national statistical collections and government funded research in the UK. The programme also covers stalking, sexual harassment, forced marriage, female genital mutilation (FGM) and 'Honour Crime'.

5. The purpose of the VVAPP programme is to ensure that services and professionals in all sectors and settings are equipped to identify and to respond to the needs of those whose mental and physical health has been affected by domestic and sexual violence and abuse. To achieve this, the VVAPP will develop evidence-based national service guidelines based on research conducted by the programme that will inform policy, improve practice and promote access to appropriate services.

6. This document highlights the important role played by the voluntary and community sector in developing and providing services to victimised individuals. In this context, the VVAPP programme has adopted a whole system approach within a strategic framework designed to bring together what is known and what is known to work in the treatment, support and care of affected individuals from across the statutory and voluntary sectors and criminal justice system.

7. The first stage of the programme will concentrate on gathering evidence from research and from experts to inform future policy on prevention and service developments. Expert Groups have been established in six areas:

(i) adult domestic violence victims, survivors and perpetrators,

(ii) adult victims of rape and sexual assault,

(iii) adult survivors of childhood sexual abuse,

(iv) child victims of domestic violence and child sexual abuse,

(v) child, adolescent and adult victims of sexual exploitation, and

(vi) adolescent and adult sexual abusers/offenders. 
8. These comprise the full range of stakeholders including over a hundred academics, professionals, service providers, service users and organisations representing victims and survivors. All experts advising the programme are listed in Annex $A$. Their role is to advise on and to quality assure the implementation of the VVAPP. Initially their expertise is supporting the programme of research being conducted as part of the VVAPP to inform the development of national service guidelines. This includes:

(i) a review of the the relevant literatures across the six areas covered by the programme,

(ii) service mapping across the sectors,

(iii) a consensus building Delphi expert consultation,

(iv) experiential research with victims, survivors and abusers to map both 'abuse and its effects pathways' and 'care and recovery pathways',

(v) a pilot and evaluation of the introduction of routine enquiry in mental health services about histories of childhood sexual and other abuse.

9. Subsequently the information gathered will be used to support the development of services and practice improvement across the sectors. There is a strategic framework in Annex B which sets out the objectives, actions and change required to improve outcomes for individual victims of this violence and abuse. What the programme aims to deliver is set out in Annex C.

10. Outcomes are defined in terms of reducing the mental illness, self harm, suicide and physical injury associated with victimisation; improving the mental and physical health and quality of life of those who have been victimised; seeking to minimise revictimisation; and for abusers - reducing continued and new offending. The overarching objective is the prevention of this violence and abuse and the prevention of its adverse effects. 
11. The VVAPP is a two year programme running until April 2007. It is jointly located within the Department of Health and the National Institute for Mental Health in England (NIMHE). The programme is tied into the relevant branches of the Department of Health: adult mental health, sexual health, child health and mental health, women's health and public health. Key elements of the programme are being taken forward jointly with the Home Office Domestic Violence Unit, Juvenile Offenders Unit, Sexual Crime Reduction Team, Victims and Confidence Unit and Criminal Law Policy Unit. All concerned are working closely with the 'violence and abuse voluntary sector'. The structure of the programme is set out in the chart in Figure 1.

\section{Figure 1: Victims of Violence and Abuse Prevention Programme Structure}
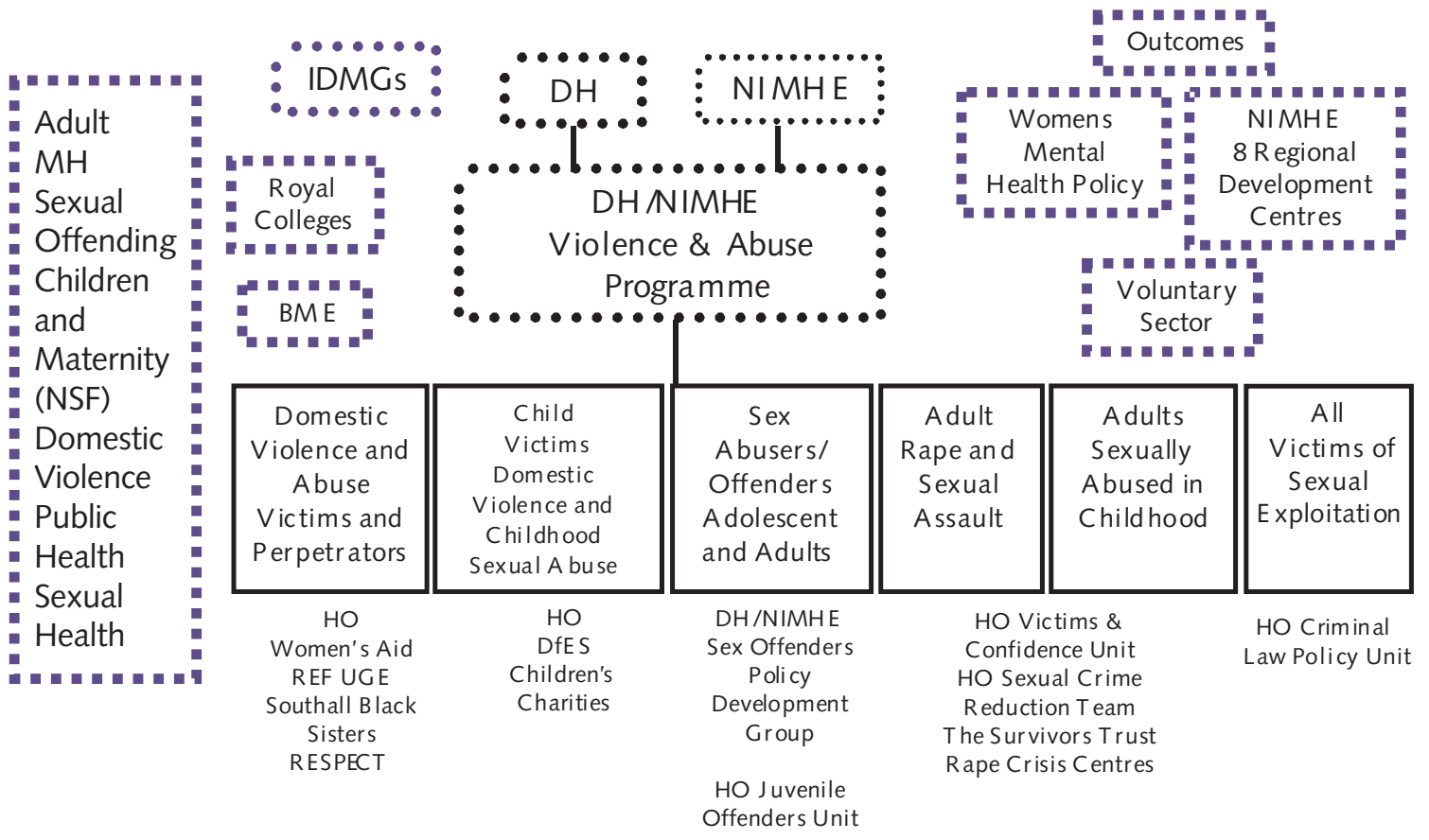
12. The purpose of this publication is to:

i. highlight the evidence base on which this programme will build;

ii. brief the full range of stakeholders about the nature and scope of the programme and how it will underpin the implementation of the domestic and sexual violence and abuse elements of the Public Health White Paper and other Department of Health and Government policy;

iii. outline the architecture and infrastructure of the programme and the multiple research methodologies that will be used to build the knowledge base in these areas;

iv. set out a strategic framework for policy and service development, new ways of working, improved practice and service evaluation; and

v. seek advice from all stakeholders with an interest in this programme on:

- how to ensure that it achieves its objectives,

- material they would like to be considered as part of the work of the programme, and

- the role they would like to play in taking this work forward.

13. All communications will feed directly into the work of the Expert Groups and all contributions will be acknowledged and credited. These should be sent by email and/or hard copy headed VVAPP Feedback to:

Professor Catherine Itzin

Director

Joint Department of Health \& NIMHE

Victims of Violence \& Abuse Prevention Programme

Room 203

Wellington House

133-155 Waterloo Road

London, SE1 8UG

Email: Catherine.Itzin@dh.gsi.gov.uk 


\section{Scope of the Programme}

14. This is a broad-based and wide-ranging programme. An initial scoping exercise and expert consultation was undertaken. Its findings have been used to define the parameters and scope of the programme. It covers child sexual abuse, domestic violence, rape and sexual assault and sexual exploitation as it affects victims, survivors and abusers, both male and female including children, adolescents and adults.

\section{Terms of Reference}

15. Its terms of reference are to address:

- the mental and physical health effects of child sexual abuse, domestic violence, rape and sexual assault, and sexual exploitation - and the links between them - for:

- professionals and services identifying and responding to the needs of:

i. adult domestic violence victims, survivors and perpetrators;

ii. adult survivors of intra and extra-familial childhood sexual abuse;

iii. adult victims and survivors of rape and sexual assault;

iv. child and adolescent victims of domestic violence and child sexual abuse;,

v. child, adolescent and adult victims of sexual exploitation in prostitution, pornography and trafficking.

vi. adolescent and adult sexual offenders (and sexual abusers not in contact with the criminal justice system);

16. The programme also covers stalking, sexual harassment, forced marriage, female genital mutilation (FGM) and 'Honour Crime'. 


\section{A Life Course Perspective}

17. The programme is adopting a life course perspective in the recognition that the effects of this violence and abuse are experienced not just in the immediate and medium term, but often over the whole of an affected individual's life (see Figure 2). Understanding and responding to the impact of abuse from a life course perspective makes it possible to focus attention and action on early interventions and prevention measures. This creates the opportunity to identify interventions that can minimise future mental and physical ill health, reduce the risks of revictimisation, and prevent abuse occurring, or reoccurring.

Figure 2: The Life Course Consequences of Childhood Sexual Abuse on Increased Risk of Sexual and Domestic Violence and Abuse, and Short Term Health Risk Behaviours and Outcomes.

Adopting a Life Course Perspective on the Impact of Childhood Sexual Abuse on Health Inequalities

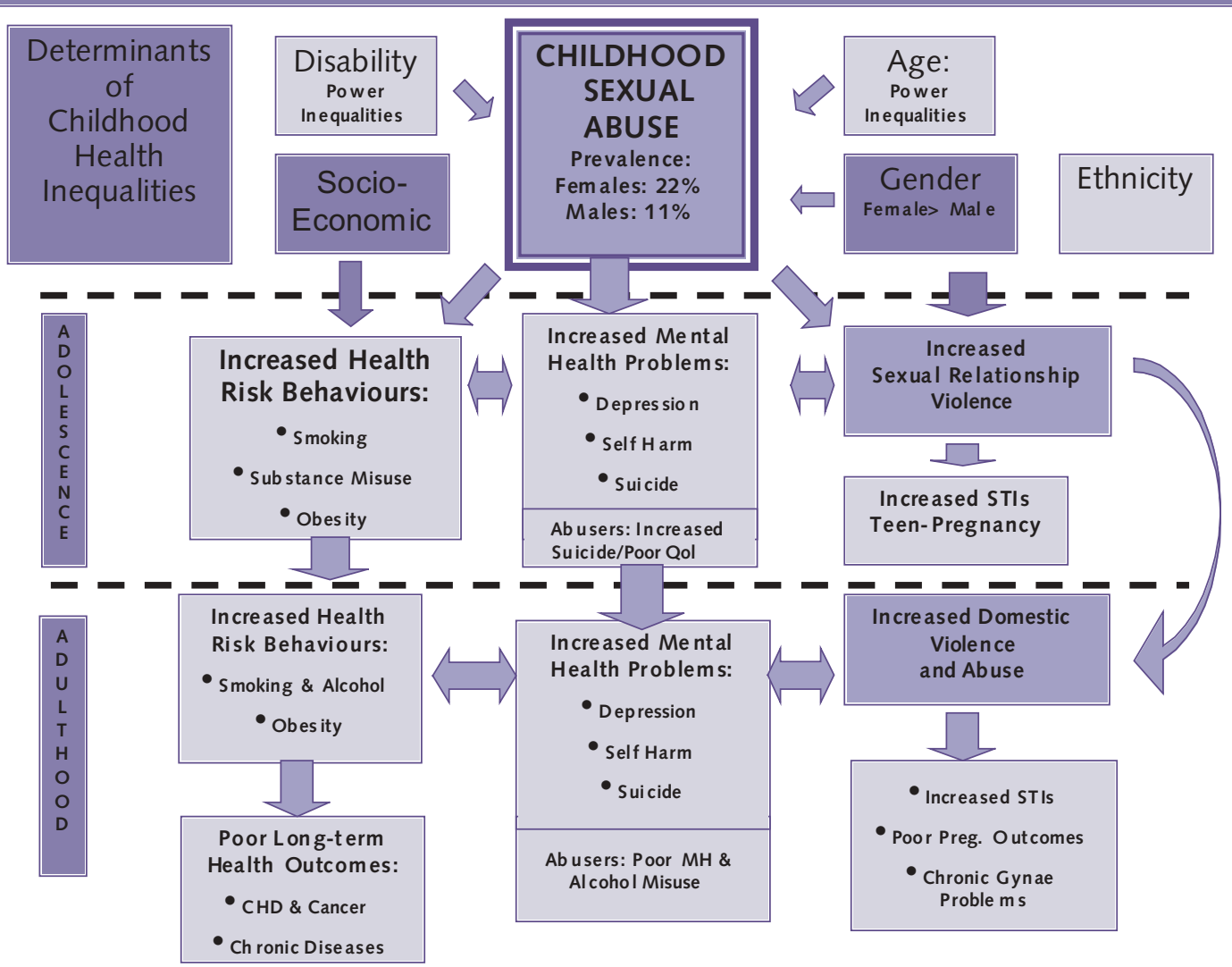

(Adapted from Nurse, J. et al 2005) 


\section{A Whole System Approach}

18. The programme brings together many strands of work from the diverse sectors and fields associated with these issues. This includes many Government and cross-Government initiatives, a wide range of voluntary and independent sector agencies, statutory health and social care services and the criminal justice system (see Figure 3 ).

\section{Figure 3: A Whole System Approach}

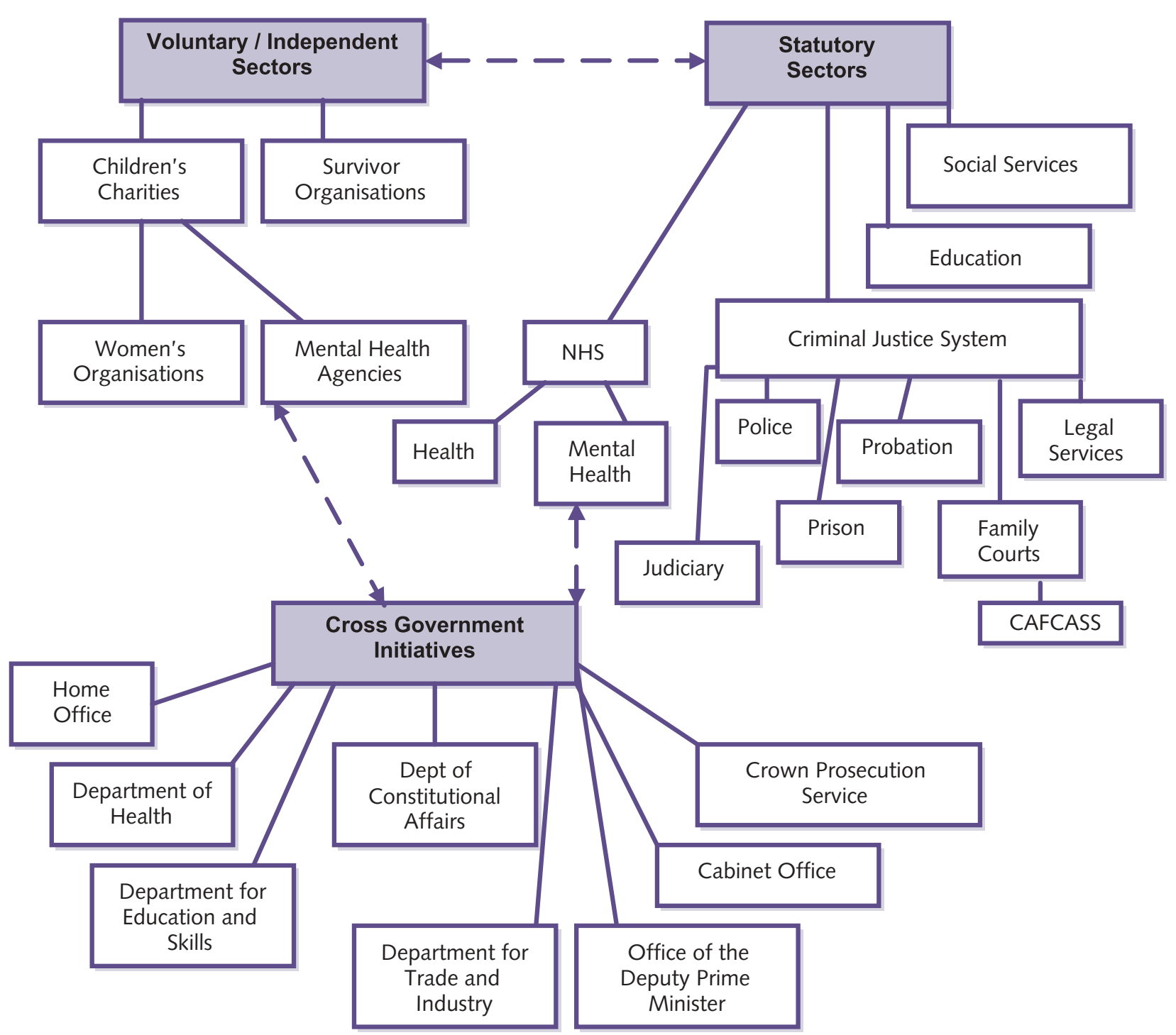


19. Services are multi-agency and much of the relevant work - both professional and academic - is multi-disciplinary. This includes child and adolescent, adult, and forensic psychiatry, clinical psychology, psychotherapy, counselling, social work, probation, nursing, general practice, A\&E and antenatal and paediatric medicine. This is the first time the full range of these issues and groups have been brought together in a health and mental health services context.

20. The programme is adopting a whole system approach which involves the many organisations which constitute the statutory sectors: $\mathrm{NHS}$ health and mental health services, social services, education and the criminal justice system including police, prison and probation services and the judiciary. It also involves the voluntary and community, and independent sectors which have been the major provider of services for individuals affected by domestic and sexual violence and abuse. These include:

- Women's Aid which supports, coordinates and represents an England-wide network of over 300 local domestic violence organisations - including REFUGE - providing over 500 refuges, helplines, advocacy and outreach services for women and children who experience domestic violence, including training, resources, help leaflets in 11 languages, and the UK wide directory of local domestic violence services: The UK Gold Book (www.womensaid.org.uk)

- $\quad$ RESPECT which represents domestic violence perpetrator intervention programmes - and associated women's support services in the community;

- $\quad$ Rape Crisis Centres which have pioneered services for women victims of rape and sexual assault, and the Survivors Trust with its $80+$ member organisations, including the one that publishes the DABS directory with its listings of $400+$ counselling and other support services for victims of childhood sexual abuse, rape and sexual violence; 
- the children's charities and the national network of Women's Aid organisations in refuges, and the many services they have developed and provided for child victims of domestic violence, of physical and sexual abuse and sexual exploitation, and for adolescent sexual abusers; and

- mental health voluntary sector organisations such as the Mental Health Foundation, MIND, Young Minds and others addressing the mental health needs of individuals affected by this violence and abuse.

21. These organisations have been providing high levels of services over decades to victims and survivors of domestic and sexual violence and abuse. They have extensive knowledge and experience of responding to the needs of these individuals including the mental and emotional distress associated with victimisation, and in providing safety, support and care of different kinds in different contexts.

22. It is not the intention of this programme to create new specialist services for affected individuals within the NHS. Rather, the whole system approach will make all of its elements visible: including a recognition throughout the system of the nature and extent of this violence and abuse, and its effects on those who are victimised; with a whole system understanding of their needs and how to meet them.

23. The main objective of the programme is to bring together and build on existing evidence, intelligence, knowledge, experience, services, practice and policy from all sectors to improve understanding, practice and services in all sectors under-pinned by Government policies and cross-Government initiatives. 


\section{The Evidence Base}

24. There is a substantial body of knowledge about the nature, extent and effects of child sexual and physical abuse, domestic violence, rape and sexual assault and sexual exploitation as it affects victims, survivors and abusers, including children, adolescents and adults both male and female.,

25. Prevalence rates for child sexual abuse and domestic violence are high. ${ }^{3,4,5,6,7}$ Underlying this are high rates of physical abuse of children. ${ }^{8}$ There is increasing evidence of co-occurrence of domestic violence and child sexual abuse as well as physical abuse, also of rape and sexual assault with domestic violence. ${ }^{9,10}$ There are also findings from research about the effects of domestic violence on the mental and physical health of children and women. ${ }^{11}$ Studies show child sexual abuse and domestic violence occurring in all social classes and ethnic groups. ${ }^{12,13}$

1 Itzin, C. (2000) Home Truths About Child Sexual Abuse London: Routledge

2 Hanmer, J. and Itzin, C. (2000) Home Truths About Domestic Violence London: Routledge

3 Mrazek, P.J., Lynch, M.A. and Bentovim, A. (1983) 'Sexual Abuse of Children in the United Kingdom' Child Abuse and Neglect 7 147-153

4 Finkelhor, D. (1994) 'Current Information on the Scope and Nature of Child Sexual Abuse' The Future of Children: Sexual Abuse of Children 4.2 31-53

5 Bradley, F. et al (2002) 'Reported Frequency of Domestic Violence: Cross-Sectional Survey of Women Attending General Practice' British Medical Journal 324, 2 February 271-274

6 Richardson, J. et al (2002) 'Identifying Domestic Violence: Cross Sectional Study in Primary Care' British Medical Journal 3242 February 274-277

7 Kelly, L., Regan, L. and Burton. S. (1991) An Exploratory Study of the Prevalence of Sexual Abuse in a Sample of 16-21 Year Olds London: Child Abuse Studies Unit, University of North London

8 Cawson, P et al (2000) Child Maltreatment in the UK: A Study of Prevalence of Child Abuse and Neglect London: NSPCC

9 Mullender, A. and Morley, R. (1994) Children Living with Domestic Violence London: Whiting and Birch

10 Walby, S. and Allen. J. (2004) Inter-Personal Violence: Findings from the 2001 British Crime Survey London:Home Office

11 Humphreys, C. and Thiara, R. (2003) Mental Health and Domestic Violence: 'I Call It Symptoms of Abuse' British Journal of Social Work 33 209-226

12 Mama, A. (2000) Violence Against Black Women in the Home in Hanmer, J. and Itzin, C. op cit. 44-57

13 Patel, P. (2000) Southall Black Sisters: Domestic Violence Campaigns and Alliances Across the Divisions of Race, Gender and Class' in Hanmer, J. and Itzin, C. op cit. 167-185 
26. Childhood sexual abuse is known to be associated with an increased risk of mental illness and a contributing factor in its aetiology for females in adolescence and adulthood, with similar effects for males. ${ }^{14}$ This is based on a substantial clinical literature.

27. There has been a growing literature on the inter-generational effects of violence and abuse, and in particular, the links for some boys between having been sexually abused as a child and subsequently perpetrating sexual abuse as adolescents and adults. ${ }^{15}$ Department of Health funded research has identified the additional role of physical abuse and 'witnessing' domestic violence together with child sexual abuse in creating this vulnerability. ${ }^{16}$ For girls, there can be a vulnerability following sexual abuse as a child to self harm and revictimisation in adolescence and adulthood. ${ }^{17}$

28. A review of the research evidence has been conducted to support the development of Government policy in these areas, and the establishment of the VVAPP. It comprised a broad-based review of the relevant literatures across all the groups covered by the programme, and covered what is known from these sources about the prevalence of this abuse and its effects on those who are victimised. See Boxes 3 and 4 for key messages from the research.

29. The findings from the research literature are not contested. They include key pieces of government funded research and national statistical collections, longitudinal studies and meta-analyses of multiple studies.

14 Kendall-Tackett. K.A., Williams, L.M. and Finkelhor, D. (1993) Impact of Sexual Abuse of Children: A Review and Synthesis of Recent Empirical Studies Psychological Bulletin 113 164180

15 Widom, C.P. (1989) The Cycle of Violence American Association for the Advancement of Science 244 160-166

16 Skuse, D., Bentovim, A. et al (1998) Risk Factors for Development of Sexually Abusive Behaviour in Sexually Victimsed Adolescent Boys: Cross Sectional Study British Medical Journal 317 175-179

17 NICE (2004) Guidelines on Self Harm London: National Institute of Clinical Excellence 
Box 3: Prevalence

- Domestic violence accounts for a quarter of all violent crime, $26 \%$ of all women are victims of domestic violence, two women a week are killed by partners/ex-partners and 30\% onsets or escalates during pregnancy. 18.19

- Thousands of children witness domestic violence every day, not just listening to verbal violence, but seeing their mothers being physically abused and sexually assaulted..$^{20}$

- $\quad$ Prevalence rates for childhood sexual abuse are high (20-30\% of girls, $5-10 \%$ of boys) and up to $20 \%$ of children are subjected to physical violence regularly. ${ }^{21,22}$

- Moreover, research suggests that in at least $40 \%$ of domestic violence cases there is also childhood physical and sexual abuse involving the same perpetrator, usually the father or father figure. ${ }^{23,24}$

- $\quad$ Rape is a significant element of domestic violence. The British Crime Survey (2001) found that 7\% of women suffer rape or serious sexual assault and that in $54 \%$ of cases the rapist is the current $(45 \%)$ or ex $(9 \%)$ partner of the victim ${ }^{25}$

- Chilhood sexual and physical abuse, domestic violence, and rape and sexual assault occur in all social classes and ethnic group. ${ }^{26}$

18 Walby, S. and Allen, J. (2004) Inter-Personal Violence: Findings from the 2001 British Crime Survey London: Home Office

19 British Medical Association (1998) Domestic Violence: A Healthcare Issue London: BMA

20 McGee, C. (2000) Childhood Experiences of Domestic Violence London: Jessica Kingsley

21 Bolen, R.M. and Russell, D.E.H. (2000) Child Sexual Abuse Prevalence: A Review and Reanalysis of Relevant Studies in Itzin, C. op cit. 169-197

22 Cawson, P. et al (2000) Child Maltreatment in the UK: A Study of Prevalence of Child Abuse and Neglect London: NSPCC

23 Walby. S. (2004) The Costs of Domestic Violence London: Department of Trade and Industry

24 Hester, M. (2000) 'Child Protection and Domestic Violence: Findings from a Rowntree/NSPCC Study' in Hanmer, J. and Itzin, C. (eds) Home Truths About Child Sexual Abuse op cit: 96-113.

25 Walby, S. and Allen, J. (2004) Inter-Personal Violence: Findings from the 2001 British Crime Survey London: Home Office

26 Hanmer, J. (2000) Domestic Violence and Gender Relations: Contexts and Connections in Hanmer, J. and Itzin, C. op cit 9-23 
Box 4: Effects on Mental and Physical Health

- Frequently reported long term mental health effects of childhod sexual abuse for women include depression, anxiety, pos-ttraumatic stress disorder, psychosis, substance abuse, eating disorders, self harm and suicide. There are similar effects for males. ${ }^{27,28}$ Moreover, various studies have reported between $50-60 \%$ of inpatients and $40-60 \%$ of outpatients in mental health services having been physically and/or sexually abused as children. ${ }^{29,30}$

- Adverse health effects of childhood sexual abuse, domestic violence and rape/sexual assault include higher rates of health risk behaviours such as smoking, and alcohol and drug misuse, risky sexual behaviour (including prostitution), eating disorders (including anorexia and obesity), sexually transmitted infections, unwanted pregnancies (including teenage pregnancies), irritable bowel syndrome and increased gynaecological problems. ${ }^{31}$

- $\quad$ There is clear evidence of the adverse effects of domestic violence on women's mental health, that it can last for many years and that it leads to increased use of mental health services. A meta-analysis of 18 studies found an average rate of posttraumatic stress disorder among victimised women of $64 \%$, a rate of depression of $48 \%$ and a suicide rate of $18 \% .{ }^{32}$

Polusny, M.A. and Follette, V.M. (1995) Long Term Correlates of Child Sexual Abuse: Theory and Review of the Empirical Literature Applied and Preventive Psychology 4 143-166

29 Jacobson, A. (1989) 'Physical and Sexual Assault Histories Among Psychiatric Outpatients' American Journal of Psychiatry: 146: 755-758.

30 Jacobson, A. and Richardson, B. (1987) 'Assault Experiences of 100 Psychiatric Inpatients Evidence of the Need for Routine Enquiry' American Journal of Psychiatry: 144: 908-913.

31 Nurse, J., Garcia-Moreno C, Phinney A, Butchart A, Clarke N.(2005) A Global Perspective on Adolescent Sexual Relationship Violence: A New Understanding for Health Outcomes and Opportunities for Prevention Departments of Gender and Women's Health/ Violence and Injury Prevention, World Health Organisation, Geneva

32 Golding, J.M. (1999) Intimate Partner Violence as a Risk Factor for Mental Disorders: A MetaAnalysis Journal of Family Violence 142 99-132 
Box 4: Effects on Mental and Physical Health (continued)

- $\quad$ There are many studies showing that domestic violence impairs children's emotional, behavioural and cognitive development. Its effects include anxiety, fear, withdrawal, highly sexualised and aggressive behaviour, reduced educational achievement, failure to acquire social competence, anti-social behaviour, and the use of drugs. ${ }^{33}$

- Various studies report a range of mental health problems following rape and sexual assault, including post-traumatic stress disorder, anxiety and panic attacks, depression, somatic symptoms, social phobia, substance abuse and suicide. ${ }^{34}$ 


\section{The Government Policy Context}

30. Part of the process of developing this programme has involved establishing a Department of Health and wider Government policy context in which the mental and physical health needs of individuals affected by domestic and sexual violence and abuse can be addressed. Relevant policy initiatives are summarised here.

\section{Department of Health}

- $\quad$ The Mental Health National Service Framework (1999) highlighted the association between child sexual and other abuse and domestic violence with mental illness and personality disorder.

- Working Together to Safeguard Children: A guide to inter-agency working to safeguard and promote the welfare of children (1999 with the Home Office and Department for Education and Employment) sets out a national framework and guidance on how all agencies and professionals in health and education services, the police, social services, the probation service and others in the statutory, voluntary and independent sectors should work together to protect children's welfare and safeguard them from abuse and neglect.

- Framework for the Assessment of Children in Need and their Families (2000 with Home Office and Department of Education and Employment) describes the assessment framework and provides guidance on how it should be used by professionals and other staff involved in undertaking assessments of children in need and their families under the Children Act 1989, including children who may be or are suffering significant harm, involving primarily social services, but also other local authority services, and health authorities which have a duty to assist.

- Domestic Violence: A Resource Manual for Health Professionals (2000) builds on and consolidates best practice professional guidelines on identification and management of domestic violence through the introduction of routine enquiry about domestic 
violence in healthcare services, setting out key principles to be applied across the NHS and underpinning the development of local protocols for domestic violence.

- The National Suicide Prevention Strategy (2001) includes as an objective 'to promote the mental health of victims and survivors of abuse, including child sexual abuse' - and domestic violence with a particular focus on self harm.

- The Women's Mental Health Strategy 'Into the Mainstream' (2002) and the Implementation Guidance 'Mainstreaming Gender and Women's Mental Health' (2003) have a strong focus on child sexual abuse, domestic violence and rape and sexual assault as causal factors in mental illness in women, and proposes that these become core issues in mental health services delivery.

- Better Prevention, Better Services, Better Sexual Health : The National Strategy for Sexual Health and HIV (2002) includes the key aims of reducing the prevalence of undiagnosed HIV and STIS and reducing unintended pregnancy rates. It identifies 'local coordination and back up for sexual assault as one of the specialist services to be provided across more than one PCT.'

- A Sexual Health and HIV Commissioning Toolkit for PCT and Local Authorities (2003) states that voluntary and community organisations have an important contribution to make to the modernisation of HIV and sexual health services. The guidelines recommend that PCTs should consider the involvement of VCOs in commissioning and planning and in service delivery, giving the VCOs the same opportunities to tender for and deliver appropriate services as PCTs and NHS Trusts.

- Personality Disorder: No Longer a Diagnosis of Exclusion (2003) sets out the Government's intentions for the delivery of personality disorder services in general mental health and forensic settings, including borderline personality disorders usually applied to women and associated with histories of child sexual abuse, self harm and suicide.

- $\quad$ Tackling Health Inequalities: A Programme for Action (2003) 'Supporting families, mothers and children' and 'Improving life 
chances for children' are key elements of this programme including making mainstream services more preventative and more responsive to the needs of children of all ages at risk from...poor physical, mental or sexual health; victimisation....and abuse'.

- $\quad$ From Here to Equality: A Strategic Plan to Tackle Stigma and Discrimination on Mental Health Grounds (2004) does not include victims of child sexual abuse, domestic violence and rape or sexual assault but this victimisation and its mental health effects carry a particularly high level of associated stigma. Action could be taken to address this..

- The NSF for Children, Young People and Maternity Services (2004 jointly with DfES)

- States that 'the abuse of a child - physically, emotionally or sexually - or neglect and domestic violence can have a serious impact on all aspects of the child's health, development and well-being which can last throughout adulthood' with 'immediate and longer term impact...including anxiety, depression, substance misuse, eating disorders and self-destructive behaviours.'

- Highlights the association between domestic violence in pregnancy as a threat to mothers and children and proposes that 'all NHS maternity care providers and Primary Care Trusts ensure that all pregnant women are offered a supportive environment and the opportunity to disclose domestic violence; and local support services and networks are developed and midwives and other health professionals involved are trained to respond appropriately.'

- Supporting Local Delivery (2004 jointly with DfES) sets out the health agenda for children and details the support that Government will provide for implementation of the NSF for Children, Young People and Maternity Services.

- $\quad$ The Public Health White Paper 'Choosing Health' (2004) identifies child physical, emotional and sexual abuse and neglect and domestic violence as public health issues to be addressed 
through a cross government strategy for tackling the physical and mental ill health associated with this (see Box 1 p...).

- $\quad$ For children it proposes to address this through the Child Health Promotion Programme set out in the NSF for Children, Young People and Maternity Services to ensure health and well-being for children and young people from birth to adulthood, including the assessment of the child's and family's needs, early interventions to address identified needs and safeguarding children from harm.

- $\quad$ For mothers and babies, the PHWP proposes to address domestic violence during pregnancy as a public health issue based on policy set out in the NSF for Children, Young People and Maternity (see above).

- For sexual health services, the PHWP sets out a programme of modernisation, including up-grading prevention services such as contraception provision in Genito-Urinary Medical (GUM) services. This will help to facilitate the joint Home Office and Department of Health development of Sexual Assault Referral Centres (SARCs) nationally as one of the Inter-Departmental Ministerial Group on Sexual Offending priorities.

- The Public Health White Paper Delivery Plan (2005) includes under 'Improving Sexual Health' the joint DH and $\mathrm{HO}$ initiative to develop Sexual Assault Referral Centres (SARCs) nationally, including services for children and adolescents. Under 'Improving Mental Health and Well Being' it includes 'Targeted action to improve the quality of patient experience for example patients from black and minority ethnic communities or victims of domestic violence such as through the joint ' $\mathrm{DH}, \mathrm{HO}$ and NIMHE violence and abuse programme'.

- $\quad$ Responding to Domestic Abuse: A Handbook for Health Professionals (2006) is a practical tool that answers the question 'what am I supposed to do if one of my patients tells me they are experiencing domestic abuse?'. It takes on board feedback from the users of Domestic Violence: a resource manual for health care 
professionals, published in 2000. It is designed to be easy-to-use, functional and accessible. It builds on good practice that is already in place across the country and will enable health professionals to respond consistently to domestic abuse.

- $\quad$ Responding to Domestic Abuse: Training Manual (2005) was jointly commissioned by the Department of Health and Home Office from the National Domestic Violence Practitioners Forum. It brings together training materials from different contexts which have been evaluated for their effectiveness to support the implementation of $\mathrm{DH}$ domestic violence policy as set out in the Handbook (see above).

\section{National Institute For Clinical Excellence (Nice) Guidelines}

- The NICE Guideline on Self Harm (2004) stresses the importance of recognising that childhood experiences of abuse and domestic violence are all associated with a range of mental disorders as well as self harm. It found a 'rich and well-established service user literature on the subject of self harm' and recommends that 'appropriate multi-methodology research on self harm as a response to child sexual and other abuse should be carried out.

- $\quad$ The NICE Guideline on Posttraumatic Stress Disorder (2004) has a strong focus on child sexual abuse, domestic violence and rape and sexual assault as causal factors in PTSD for children and adolescents as well as adults.

- Other NICE Guidelines relevant to child sexual abuse, domestic violence and rape and sexual assault include: adult depression, depression in children, bi-polar disorders, anxiety, disturbed behaviour, obsessive-compulsive disorders, schizophrenia, intrapartum, ante and post natal care, and incontinence. 


\section{Other Government Departments}

\section{Home Office}

- Safety and Justice (2003) the Government's consultation document on its domestic violence proposals identifies the particular contribution that the NHS has to play in domestic violence, not only because of the impact on victims' health, but also because the NHS may be the first contact point with professionals who can recognise and intervene in the situation.

- A New Deal for Victims and Witnesses: National Strategy to Deliver Improved Services (2003) has a strong focus on specific groups of victims. These include: children and young people including (a) child victims of sex offenders, (b) children at risk of becoming sexual abusers in adolescence or adulthood, and (c) children involved in prostitution. It includes victims of rape and sexual assault, victims of domestic violence, victims of repeat victimisation (such as domestic violence victims), victims of human trafficking (including both children and women), and witnesses (including children giving evidence). The strategy also has a strong focus on working in partnership with the NHS through local Crime and Disorder Reduction Partnerships, and developing SARCS Sexual Assault Referral Centres - nationally based on local partnerships.

- Paying the Price: A Consultation Paper on Prostitution (Home Office 2004) This paper expressed Home Office concerns about the damage of street prostitution to individuals and communities, and in particular (i) the grooming of children and young people into abuse through prostitution, (ii) the high level of childhood physical and sexual abuse histories and problematic drug dependency amongst those involved in prostitution, and (iii) the need for action against pimps, drug dealers and the demand side of prostitution.

- A Coordinated Prostitution Strategy and a summary of responses to Paying the Price (2006) The key objectives of the strategy are to: challenge the view that street prostitution is inevitable and here to stay; achieve an overall reduction in street prostitution; 
improve the safety and quality of life of communities affected by prostitution; and reduce all forms of commercial sexual exploitation. This will involve prevention and early interventions to stop children and young people becoming engaged in prostitution; tackling the demand that creates the market in prostitution; developing routes out for those trapped in prostitution; brining to justice those who exploit individuals through prostitution, including trafficking.

- Consultation: On the Possession of Extreme Pornographic Material (2005) This public consultation document sets out options for creating a new offence of simple possession of extreme pornographic material which is graphic and sexually explicit and which contains actual scenes or realistic depictions of serious sexual violence, bestiality or necrophilia. This legislation is intended to respond to the wide range of extreme pornographic material available via the Internet, and uncontrollable by existing legislation. The Home Office intention in proposing a possession offence is to try to break the demand/supply cycle for material which might encourage or reinforce interest in violent and aberrant sexual activity.

- Corporate Alliance Against Domestic Violence (2005) is a group of progressive companies and organisations working individually and collectively to address the impact of domestic violence in the workplace. The Alliance aims to raise awareness and reduce the human and economic impact of domestic violence which represents a quarter of violent crime, affecting $25 \%$ of women and costing UK business over $£ 2.7$ billion a year. By proactively addressing the issues, organisations can both reduce the costs to their business and help prevent the occurrence of domestic violence.

- Domestic Violence National Delivery Plan (2006) As part of the development and implementation of the Government's National Delivery Plan on Domestic Violence and the ODPM's 'Change Up Programme', the Home Office have commissioned Women's Aid to develop service standards for the domestic violence voluntary sector. This is part of the focus in the National Delivery Plan on 
developing the domestic violence workforce, tied in with the broader work of the Sector Skills Councils which are engaged in comprehensive workforce development.

\section{HM Treasury}

- The HMT Child Poverty Review (2004) identifies 'the effects of child sexual abuse and domestic violence on children' as being 'associated with an increased lifetime prevalence of mental illness' and with 'mental health problems in childhood.'

\section{Department of Trade and Industry}

- Delivering Gender Equality (2003) includes a focus on 'crimes such as domestic violence, rape and trafficking as overwhelmingly (though not exclusively) committed by men against women', and a commitment 'to tackling these crimes as a priority area for Government.'

- The Costs of Domestic Violence (2004) In this report commissioned by the Department of Trade and Industry Sylvia Walby reviews some of the very substantial literature on the effects of domestic violence on women's health and mental health covering depression, PTSD and suicide and calculates the costs to health and social services at $£ 1.24$ billion.

- The Women's National Commission (WNC) Violence Against Women Working Group includes representation from over 50 organisations, and works in partnership with Amnesty International UK, the TUC and the National Federation of Women's Institutes. It seeks to ensure a joined up approach across Government to all forms of violence against women, including but not limited to domestic and sexual violence, FGM, trafficking, 'honour crimes' and forced marriages. This group of organisations now form the End Violence Against Women Coalition Campaign. More information can be found at www.endviolencegainstwomen.org.uk'. 'The WNC Sexual Violence Sub-groupaims to develop a cohesive and effective voice to Government on action needed to address the sexual violence. 


\section{Department for Education and Skills}

- $\quad$ Every Child Matters Green Paper (2003) marked a shift of focus from child protection to improving the health and well being of all children.

- $\quad$ Every Child Matters: the Next Steps (2004) set out three main areas of Government policy: (i) supporting parents and carers by providing universal services, (ii) early intervention and effective protection through improved multi-agency information sharing, (iii) accountability and integration of services at local, regional and national levels.

- Working Together to Safeguard Children: A guide to inter-agency working to safe guard and promote the welfare of children (2006) (Department of Education and Skills with Department of Health) This document updates guidance published in 1999 in the context of the NSF for Children, Young People and Maternity Services, Every Child Matters and the Children Act (2004), and incorporates 'What To Do If You're Worried A Child Is Being Abused' (2003). It provides detailed guidance on the multi-agency management of individual cases with a focus on family assessments and child welfare a well as child protection.

\section{Office of Deputy Prime Minister (ODPM)}

- UKRefugesonline (2002) was funded by the ODPM and Comic Relief. It is managed by five partner organisations including four Women's Aid federations - England, Northern Ireland, Scotland and Wales, as well as REFUGE. It provides a secure (closed) online system of domestic violence services across the UK containing up to date vacancy details and view vacancies. Information about services is collected, managed and owned by the individual Women's Aid federations who also manage the service use. The 24 hour National Domestic Violence Freephone Helpline (0808 2000 247) run in partnership between Women's Aid and REFUGE is a key user of the online service. 
- $\quad$ Supporting People (2003) For women who have lived with domestic violence Supporting People recognises their need not only for the provision of safe accommodation and associated housing-related support in refuges or in the community, but also for other support services including health care, emotional support, access to legal advice, advocacy and support for children and young people.

- Social Exclusion Unit Report on 'Mental Health and Social Exclusion' (2004) identifies victims of abuse - specifically those who have been sexually abused in childhood and adult victims of domestic violence as amongst those who often experience mental health problems.

\section{Legislation}

- Adoption and Children Act (2002) came into force on 31 January 2005. The Act sets out a new legal framework for children by defining living with or witnessing domestic violence as constituting 'significant harm'.

- The Sexual Offences Act (2003) came into force on 1 May 2004. The Act overhauls the sexual offences framework and includes provisions to give children and adults better protection against sexual abuse and exploitation.

- Domestic Violence Crime and Victims Act (2004) came into force in April 2005. The Act addresses some of the proposals made in the Government consultation paper Safety and Justice (2003) to improve legal protection for victims of domestic violence: making common assault an arrestable offence and mandatory murder reviews following any domestic violence murder.

- The Children Act (2004) translated many of the recommendations of Every Child Matters into law, including a Children's Commissioner for England.

- Mental Health Bill (2006) is intended to replace the Mental Health Act 1983. It provides for the compulsory treatment of people with a mental disorder if treatment is essential to protect themselves or others from harm. 
- Equality Bill (2005) creates a Gender Equality Public Sector Duty to which all public bodies will be legally bound from April 2007. All such organisations will be required to eliminate discrimination and actively promote equality of opportunity between men and women, that is equity of outcomes for women and men in all aspects of police, workforce issues and service delivery. Guidance will be developed in due course to clarify how and when private sector bodiessuch as hospitals or prisons are subject to the duty'.

\section{Cross Government Initiatives}

- Inter-Ministerial Group on Domestic Violence

- Inter-Departmental Ministerial Group on Sexual Offending

These groups enable Ministers from all Government departments to bring together their relevant policy initiatives and to work together to ensure they are effectively joined up strategically and in practice at national and local levels.

\section{Summary}

31. There are now a substantial number of high priority high profile cross Government policy initiatives on which to build to improve service responses to victims of domestic and sexual violence and abuse, including children, adolescents and adults, both male and female not just in mental health services but throughout the NHS, social services and housing, and (for abusers) the criminal justice system. 


\section{The Purpose of the Programme}

32. The purpose of the programme is to ensure that services and professionals in all sectors and settings are equipped to identify and provide effective interventions for those whose mental and physical health has been affected by domestic and sexual violence and abuse, and that prevention opportunities are developed across Government and non-governmental organisations.

33. Research has shown that women experiencing domestic violence come into contact with up to ten agencies before their needs are recognised. ${ }^{35}$ Almost all of them come into contact with the NHS through GPs, antenatal care, A\&E, and mental health services. The majority are not able to identify themselves and their children as needing treatment and care for the effects of domestic violence on their health and mental health, nor to secure access to information and support.

34. In the context of its policy on children, young people and maternity services and on public health, the Department of Health is looking to provide more effective interventions for victims of domestic violence. Initially, this will involve the introduction of a routine enquiry and discussion about domestic violence in antenatal services to ensure that all pregnant women are routinely offered information about domestic violence and sources of help, and a supportive environment to enable them to talk about their experiences if they wish to do so.

35. The position of adults who were sexually abused in childhood is similar. The Department of Health Women's Mental Health Strategy Into the Mainstream (2002) noted that a high proportion of women in contact with mental health services had histories of childhood sexual abuse, even more so in secure services and the special hospitals. These are often women experiencing severe mental distress, including self harm, whose needs are not being effectively met because the root 
cause of their mental illness in child sexual abuse is not being identified and addressed.

36. The Women's Mental Health Strategy Implementation Guidance Mainstreaming Gender and Women's Mental Health (2003) proposes introducing exploration of childhood sexual abuse, domestic violence and rape and sexual assault routinely as part of assessment and care planning in mental health services. In particular this would focus on sexual abuse in childhood given its prevalence amongst women and the severity of its effects on their mental health.

37. Within the VVAPP - as part of the Women's Mental Health Strategy implementation - a Mental Health Trust Collaboratve project has been established to develop and pilot a protocol for 'routine enquiry' in mental health services assessment and care planning about sexual and domestic violence and abuse experienced either as a child and/or as an adult in ways that are appropriate to different settings.

38. At the same time, this routine enquiry in mental health services project will bring together and make accessible information about how to respond to these issues, how to access specialist services and support for those individuals who are identified as affected, and how to provide them with treatment, support and care that is known to be effective in responding to their needs. 


\section{What the Programme Will Do}

\section{Conducting a Programme of Research}

39. The VVAPP programme is adopting an evidence-based approach throughout. A key objective is to generate authoritative validated information and knowledge with regard to:

- what is known about the domestic and sexual violence and abuse experienced by those affected (i.e. nature, extent, effects, needs);

- what is known to work in their treatment and care;

- what services are currently available to meet the needs of these individuals;

- what gaps there are in practitioner knowledge and service provision;

- what steps are required to remedy this.

40. It is building on the research and statistical data reviewed in developing and establishing the programme. Primarily, however, it will involve research being conducted or commissioned as part of the programme. This includes a critical review of the literatures across all six areas covered by the programme; service mapping across sectors; and a DELPHI expert consultation as a consensus building methodology to survey practice. At the heart of the programme will be the voice and experience of those who have been victimised 
Figure 4: What is known and what is known to work

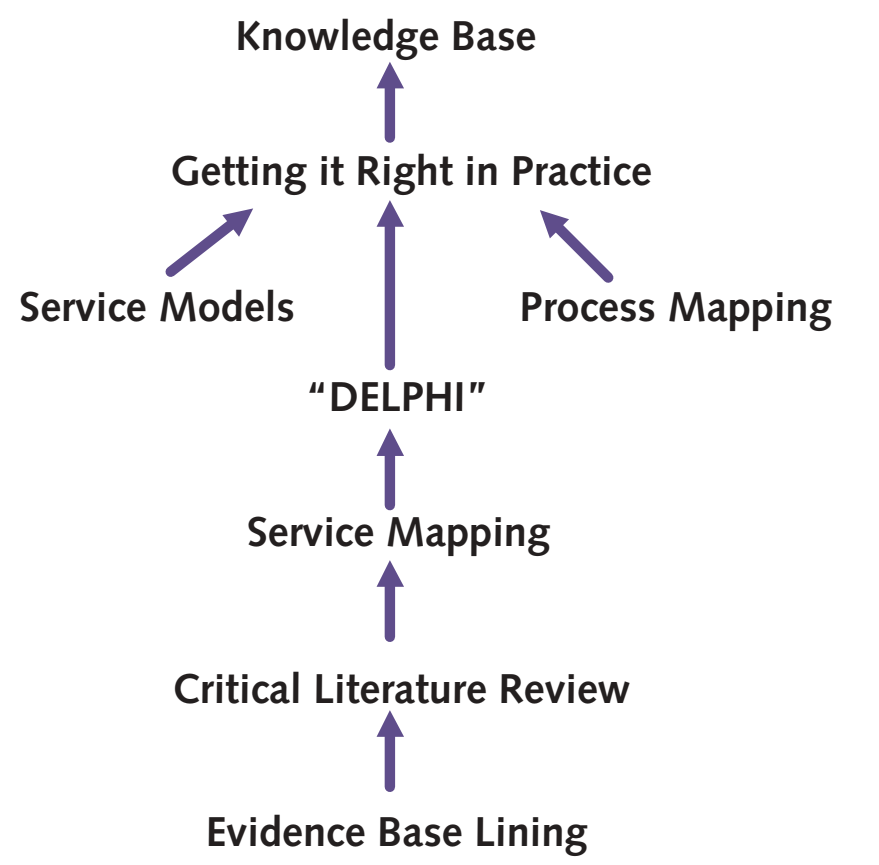

41. Fundamental to the integrity and quality of the guidance the programme will produce is its use of multiple research methodologies to establish the evidence base. This is illustrated in Figure 4 above and described below.

i. A critical literature review will be conducted across the areas covered by the programme building on: the NICE Guidelines on Self $\mathrm{Harm}^{36}$ and PTSD ${ }^{37}$; the systematic review of domestic violence interventions commissioned as part of the Department of Health's Policy Research Programme ${ }^{38}$; and the review of the literature undertaken to develop Department of Health policy and to establish this programme. It will take advice from leading experts in the fields covered by the programme and develop with them an appropriate review methodology that includes both qualitative and quantitative research reviewed systematically. 
ii. The service mapping exercises will build on the Department of Health's annual adult mental health services and child and adolescent mental health services (CAMHS) mapping methodologies. They will also build on mapping exercises conducted by voluntary, independent and criminal justice sector organisations, eg:

- UKRefugesonline (2002) funded by the ODPM and Comic Relief, and managed by the four national Women's Aid federations (England, Northern Ireland, Scotland and Wales) as well as REFUGE,

- the UK Gold Book - a guide to refuge and domestic abuse services available from Women's Aid, which provides public contact details for refuge and domestic violence services for women and children,

- the directory of services for victims of rape, sexual violence and child sexual abuse produced by Directory and Book Services (DABS) a member organisation of the Survivors Trust,

- a mapping of services for adolescent sexual abusers commissioned by the NSPCC, National Organisation for the Treatment of Abusers (NOTA) and Youth Justice Board,

- the mapping of services for child victims of sexual abuse by the NSPCC/DfES,

- $\quad$ the directory of services mapped by RESPECT of domestic violence perpetrator intervention programmes across sectors.

iii. A DELPHI Expert Consultation is being conducted across all areas covered by the programme involving the full range of experts from victim and survivor organisations to the Royal Colleges and professional bodies, including police, probabtion and prisons. DELPHI is a robust research methodology which involves panels of experts who provide their views anonymously about specified topics. It is an iterative process that produces both qualitative and quantitative data and ranks its findings according to levels of 
agreement. In this way it establishes where there is and is not consensus on a topic.

iv. Experiential research will be conducted by and with victims, survivors and service users (including abusers). This will involve mapping 'abuse and effects pathways' from childhood victimisation and subsequent revictimisation to the health and mental health and social problems associated with this. It will also map 'care and recovery pathways' from their routes into the services they need - or their difficulties in finding or being able to access those services, including what services or interventions they found, and found to be effective or ineffective. A methodology will also be sought to chart the inner processes they have discovered to understand and improve their health and mental health and quality of life. In doing this the programme will draw significantly on what the NICE Guidelines on Self Harm (2004) describe as the "wealth of survivor literature on the subject of self harm, particularly regarding the meanings associated with these acts'.

42. An important element of the overarching methodology of the programme is the establishment of Expert Groups comprising key academics, professionals, service providers, and organisations representing victims, survivors and abusers. These include:

(i) adult domestic violence victims, survivors and perpetrators;

(ii) adults sexually victimised in childhood;

(iii) adult victims of rape and sexual assault;

(iv) child victims of domestic violence and child sexual abuse;

(v) child, adolescent and adult victims of sexual exploitation in prostitution, pornography and trafficking, and

(iv) adolescent and adult sexual abusers/offenders.

43. Their task will be to advise on and to quality assure the implementation of the various methodologies outlined above to map services, to identify effective interventions and to develop national 
service guidelines based on what is learned from the research conducted by the programme. Panels of experts are also being established in each of the programme's six areas to participate in the DELPHI expert consultation.

44. In addition to the Expert Groups and the DELPHI experts, the programme has established a panel of Specialist Advisers whose expertise as academics or methodologists or practitioners, or as people with personal or professional or policy experience over-arches all of the areas and issues covered by the programme.

45. Amongst the Specialist Advisers are victims and survivors whose task will be to ensure that the programme delivers improved outcomes for individuals, to oversee the abuse effects and care pathways mapping, and to advise on other elements of the programme.

46. Alongside this will be a scoping and consultation process with the social care sector, involving both social services and education through the DfES. This will seek to identify how to approach the mapping of relevant services and the implementation of a DELPHI exercise given the scale of change in children's services and social care that have been taking place.

\section{Deliverables}

\section{Research Reports and Publications}

47. The findings from the research conducted by the programme will be published in reports for the Department of Health, Home Office and other Government departments, and in relevant professional and academic journals. 


\section{Service Mapping Databases}

48. A key product of the service mapping exercises will be the potential to establish:

service mapping databases across sectors for each group

49. These would build on already existing service mappings in both the statutory and voluntary sectors across all six areas covered by the programme. They would enable PCT commissioning of specialist services from the voluntary and community and independent sectors, and referrals to those services by generic health and mental health service providers. They would enable the many voluntary sector organisations providing counselling and other therapeutic interventions for victims of rape and sexual assault, domestic violence, sexual exploitation, adult survivors of childhood sexual abuse, and adolescent/adult sexual abusers to become part of a whole system of voluntary and statutory services providing interventions for people with mental health problems.

50. These databases wouldl enable health care professionals to provide those experiencing domestic and sexual violence and abuse with information on how to access services and support for themselves and their children as part of the introduction of routine enquiry about domestic violence in (initially) antenatal services and in mental health services about (primarily) childhood sexual abuse.

51. Likewise establishing a national telephone helpline for victims of rape and sexual abuse as the Home Office has proposed to do depends on an available and accessible database of statutory and voluntary sector services to underpin it. The availability of this information should also encourage greater partnership working between the statutory, voluntary and criminal justice sectors.

\section{National Service Guidelines}

52. The other major products derived from the research being conducted as part of the VVAPP programme will be evidence-based knowledge to inform the development of: 
national service guidelines and training materials,

53. The national service guidelines will cover:

- $\quad$ values and principles

- $\quad$ strategies and policies for prevention and early intervention

- therapeutic interventions, including psychological therapies

- $\quad$ service models

- $\quad$ practice guidance

- protocols

- $\quad$ training

54. Findings from the literature review will help to identify what is known about the nature, effects, needs and interventions in these areas. These will be used to inform the guidelines, as will information obtained from the mapping exercises about provision across the sectors, including gaps. The DELPHI surveys will elicit where there is and is not consensus from the full range of stakeholders in each field. The experiential research and care pathways mapping based on the experience of those who have been victimised and revictimised will inform the guidelines throughout.

55. The VVAPP will liaise with the National Institute for Clinical Evidence on the development of NICE guidelines relevant to the mental health effects of child sexual abuse, domestic violence, rape and sexual assault and sexual exploitation through the normal Department of Health and NIMHE stakeholder channels. The programme will also develop its national service guidelines in consultation with NICE. 
56. The implementation of the first stage of the VVAPP as outlined here will take place over a two year period to April 2007. Materials produced from this work are intended to support improvements in outcomes for individuals and organisations throughout the system as a whole, across sectors, services and settings. These will cover:

- policy development

- $\quad$ service planning, redesign and development

- $\quad$ new ways of working

- improved practice

- $\quad$ service evaluation

- $\quad$ evaluating outcomes for individuals

57. Any formal programme to support these processes would be subject to a subsequent scoping exercise to be undertaken independently from the activities set out in this document. However, within the overall methodology of the first stage of the VVAPP, the Mental Health Trust Collaborative Project to pilot the implementation of the violence and abuse elements of the Women's Mental Health Strategy will provide a model for service and practice improvement and the evaluation of outcomes for individuals. In addition, the Expert Groups will be asked to advise on the development of an implementation methodology.

58. Moreover, within this document, there is a strategic framework (in Annex B) for a 'whole system approach' to service development and outcomes improvement for the full range of stakeholders. The deliverables expected from the VVAPP programme to support this change process are specified in Annex $\mathrm{C}$. 


\section{The Role of the Royal Colleges and Professional Bodies}

59. In response to its consultation paper on domestic violence Safety and Justice (2003) the Home Office received comments from the Royal Colleges of GPs, Midwives, Nursing, and Obstetricians and Gynaecologists. These highlighted the need for:

- $\quad$ education and training for medical practitioners and managers including the needs of children and the importance of confidentiality (Royal College of General Practitioners)

- $\quad$ good guidance supported by training and awareness raising for health professionals asking about domestic violence (Royal College of Midwives);

- a national 24 hour helpline and information line on refuges, legal advice, benefits and how to help the children (Royal College of Nursing)

- further research on prevalence and models of intervention, with a 24hour helpline to advise professionals dealing with domestic violence (Royal College of Obstetricians and Gynaecologists)

60. During 2005 the Department of Health invited members of the Royal Colleges to advise Ministers on the practicalities of taking forward the commitment in the NSF on Children, Young People and Maternity Services and the Public Health White Paper 'to provide a supportive and enabling environment within antenatal care for women to disclose domestic violence'. On their recommendation, the Department of Health will begin the gradual introduction of routine enquiry and discussion concerning domestic violence with all pregnant women in antenatal services.

61. The Royal Colleges and professional bodies have an important role to play in improving practice and outcomes for victims of domestic and sexual violence and abuse. Many have taken steps to address these issues through policies, position papers, reports and fact sheets on domestic violence, rape, child abuse and neglect (Royal College of Psychiatrists), child protection (British Psychological Society), and adults sexually abused as children, domestic violence and rape (Royal 
College of Nursing). These organisations have indicated an interest in the aims of the VVAPP Programme and a wish to support its implementation. Initially they are contributing to the Delphi expert consultation.

61. The focus of the VVAPP programme will be primarily on the mental health effects associated with this abuse, and on the mental health needs of affected individuals, although links will be made with the physical health effects to highlight the wider public health impact of abuse.

62. The focus in the first phase of the service mapping will be the voluntary and community sector, the independent sector and the criminal justice system. Groundwork has been done in these sectors and the programme's methodologies are in an advanced state of development.

63. In parallel, arrangements will be put in place to take forward service mapping in the statutory health and social care sectors in consultation and working closely with the Royal College of Psychiatrists, the British Psychological Society, the Royal College of Nursing and other professional bodies including the Bristish Association of Social Work and Association of Directors of Social Services. 


\section{The Role of the Violence and Abuse Voluntary and Community Sector (VCS)}

64. The violence and abuse voluntary sector is a major provider of specialist services to victims of domestic and sexual violence and abuse, and to abusers in the community. It has a critical role to play in improving understanding and practice in the statutory sectors.

65. The Department of Health funds voluntary and community sector organisations through its Section 64 Grant. For example, funding has gone to Women's Aid to survey health service responses to victims of domestic violence, and (separately) mental health service responses to domestic violence and substance abuse. The findings have been reported in a series of leaflets, posters and publications (including Women's Aid's Domestic Violence, Mental Health and Substance Use Project - Good Practice Guidelines 2005;';9 Struggle to Survive Challenges for delivering services on mental health, substance misuse and domestic violence 2004 ${ }^{40}$; and Health and Domestic Violence: Two Years On Survey $2002-2003^{41}$ ).

66. REFUGE was funded over a three year period to develop psychological therapies for women in their refuges escaping domestic violence. A Domestic Violence Handbook for Mental Health Professionals has been commissioned as part of the VVAPP to make what has been learned from this work more widely available.

67. The Survivors Trust with its $80+$ member organisations (and Survivors UK for male victims of sexual violence and abuse) were funded through the Mental Health Section 64 grant in 2004-2005. Southall Black Sisters, the Eating Disorders Association and the Bristol Crisis Service for Women were selected for funding in 2005-2006.

39 Barron, J. (2005) Domestic Violence, Mental Health and Substance Misuse Project - Good Practice Guidelines Bristol: Women's Aid

40 Barron, J. (2004) Struggle to Survive: Challenges for Delivering Services on Mental Health, Substance Misuse and Domestic Violence Bristol: Women's Aid

41 Barron, J. (2004) Health and Domestic Violence: Two Years On Survey 2002-2003 Bristol: Women's Aid 
The Home Office through its Victims and Confidence Unit have also established a grant over two years from 2004-2006 to fund voluntary sector services for victims of sexual crime, and in particular for rape crisis services.

68. There is a recognition that the violence and abuse voluntary sector (and its infrastructure) has been developed in a context of long term historic under-resourcing, and that this will need to be addressed if it is to play a role in the provision of specialist services, and in strategy and policy development partnerships.

69. In the provision of mental health services, the mental health voluntary sector plays a critical role. For that reason, the Department of Health and National Institute for Mental Health in England have made a substantial investment in developing capacity, sustainability, quality standards and clinical governance in that sector, and in particular with regard to mental health telephone helplines. This has produced:

i. work with NHS Direct to establish the infrastructure and expertise to handle advice on mental health problems

ii. establishing the Mental Health Helplines Partnership (MHHP);

iii. a report on Developing an Investment Framework for Mental Health Helplines (commissioned from PriceWaterhouseCoopers);

iv. launching the Mental Health Helplines Partnership Quality Standard Workbook;

v. publication of Mapping Clinical Governance in Voluntary Sector Organisations

70. For the medium and longer term, the Department of Health and NIMHE are working with the Home Office - through the Victims of Violence and Abuse Prevention Programme - to explore ways in which capacity and sustainability can be developed in the violence and abuse voluntary sector building on the mental health voluntary sector development approach. 
71. In the immediate and short term, the violence and abuse voluntary sector - and the victims of domestic and sexual violence and abuse they represent - will be making a substantial contribution to taking the work of the VVAPP programme forward as Expert Group and DELPHI Expert Panel members and Specialist Advisers. 


\section{The Role of the Criminal Justice System}

72. The Prison and Probation Services and Youth Justice Boards in England - and some specialist NHS forensic services - have developed programmes for adolescent and adult sexual offenders using psychological theories and psychological therapies. In the criminal justice system, there are accredited programmes developed from the Home Office What Works initiative.

73. Similarly there are interventions with domestic violence perpetrators. The Probation Service piloted and is now rolling out in its 42 regions domestic violence perpetrator programmes for offenders (IDAP - the Integrated Domestic Abuse Programme). Programmes for perpetrators and associated women's support services are currently provided in the community by the voluntary sector organisation members of the umbrella group RESPECT.

74. However, most sexual abusers and domestic violence perpetrators never come into contact with the criminal justice system, and these programmes provide models that could be developed as community interventions in a health or mental health services context.

75. The Department of Health has been working with the Home Office Juvenile Offenders Unit for some time and with academics and service providers on identifying 'the needs of young people who display sexually harmful behaviours and the effectiveness of interventions and service approaches to meet these needs and to prevent sexually abusive and criminal behaviour'. A report on the joint work will be amongst the initial set of publications arising out of the work of the VVAPP.

76. A joint Department of Health and NIMHE Sex Offender Treatment Mental Health Policy Development Group has been established comprising Home Office and other government department officials, voluntary and independent sector providers of services for adolescents and adults and key academics and practitioners. This group is acting as the Expert Group on adolescent 
and adult sexual abuser/ offenders, advising and quality assuring the research being conducted as part of the programme. It also has a wider remit and has commissioned - jointly with the Home Office a National Strategy for Young People who Sexually Abuse.

77. Prevalence levels of 'violence at home' and sexual abuse in childhood are high amongst people in prisons, both males and females. Prisons are increasingly recognised as important settings in which to develop initiatives to improve the health and mental health of such victims. The new joint Department of Health/Home Office Division of Health Partnerships National Offender Management Service (NOMS) will provide an opportunity to develop work such as that being undertaken in selected male prisons to promote awareness of those who have been sexually abused prior to entering prison.

78. There is also a pilot project within the women's prison estate to address the effects of domestic violence. There are prison mental health leads in each of the NIMHE Regional Development Centres with the potential to work with women's mental health leads in the RDCs on issues - such as self harm - which is frequent amongst women in prisons with a history of sexual abuse in childhood.

79. The police have been at the front line of responding to victims and perpetrators of domestic violence, child sexual abuse, rape and sexual assault, and commercial sexual exploitation including prostitution, pornography and trafficking, involving children, adolescents and adults both male and female. They play a key role in multi-agency working on Area Child Protection Committees (now Local Safeguarding Children Boards) and Multi Agency Public Protection Agencies (MAPPAs). The police have been at the forefront in responding to and handling sexual offences against children. Through the Delphi expert consultation, the VVAPP programme is bringing together and building on their knowledge and experience. 


\section{Focus on prevention - Partnership Working at National, Regional and Local Level}

80. Partnership working across Government and across sectors is a Ministerial priority with regard to victims of domestic violence and sexual crime and there are Inter-Departmental Ministerial Groups on Domestic Violence and Sexual Offending to support this. In particular, there is a priority on working with those who have been victimised and organisations representing their interests or providing services which address their needs.

81. The Regional Government Offices, and the Regional Public Health Groups can play a key role in ensuring opportunities for prevention and early intervention are maximised by cross-sectoral working with regional government organisations. This includes working with Sure Start on developing parent training skills that address abuse, and the Home Office in developing early approaches for high risk behaviour groups. Regional Government Offices will be working in close partnership with national level and local services, in ways that can support the delivery and implementation of the VVAPP programme. Strategic Health Authorities also have a key role to play.

82. A current example of cross Government and cross sector work is the joint Home Office and Department of Health initiative to develop Sexual Assault Referral Centres nationally. SARCs are a 'one stop' location where victims of sexual assault can receive medical care and short term trauma counselling whilst at the same time having the opportunity to assist the police investigation, including facilities for high standard forensic examination. SARCs are based on local partnerships between the police, Primary Care Trusts (PCTs) and voluntary sector organisations, and in particular the Rape Crisis voluntary sector.

83. As part of the national SARCs development initiative, the Home Office and Department of Health are taking steps to support Primary Care Trusts to work with police and rape crisis services locally, through the Crime and Disorder Reduction Partnerships (PCTs are now amongst the 'responsible authorities' in CDRPs), Strategic Health 
Authorities, Sexual Health leads in PCTs and existing Sexual Health Partnerships.

84. Joint Home Office and Department of Health national service guidelines on the development of SARCs was the first publication in October 2005 - arising out of the work of the VVAPP programme.

85. A National Sexual Violence Conference was organised by the Home Office, Department of Health (VVAPP), Crown Prosecution Service and Association of Chief Police Officers in November 2005. Its programme included victims and survivors both male and female, voluntary organisations providing services for victims and survivors, Department of Health and Home Office Ministers, the Government's National Director for Primary Care, SARC managers, ACPO leads and police forces, and members of the Judiciary with a focus on delivering strategic partnerships and improving practice.

\section{Improving Outcomes for Victims, Survivors and Service Users (including Abusers)}

86. The aims of this programme are to improve practice and outcomes for individuals by:

- $\quad$ reducing the mental illness, self harm, suicide and physical injury associated with victimisation;

- increasing safety and minimising revictimisation;

- improving the quality of life of victims and survivors; and

- $\quad$ where possible preventing continued and new offending, through early and effective interventions with abusers in both the criminal justice system and the community.

87. One element of the programme will focus on how statutory and voluntary sector organisations and the criminal justice system can contribute to achieving these outcomes for victimised individuals. It will also focus on how organisations can benchmark the effectiveness of their practice and interventions in the treatment and care of those affected. This element of the VVAPP programme will build on the 
Department of Health's work on developing outcomes measures for individuals in receipt of mental health services. It will look at identifying outcomes at individual patient and clinical practitioner level, and at clinical practice, service and organisation levels.

88. The literature review, the service mapping, the experiential research and care pathway mapping for victims, survivors and abusers, and the DELPHI expert consultation conducted as part of the VVAPP programme all include substantial victim and survivor input. Findings from this research will be available to support improvements in outcomes for individuals and clinical governance across sectors.

89. The VVAPP programme as a whole will be supported by Specialist Advisers comprising individuals with personal experience of domestic and sexual violence and abuse and its effects, and with personal experience of statutory health and mental health, social and criminal justice system services. They will be tasked with using their experience of services in all sectors, to advise on all elements of the programme, including the interventions they have found to be most effective to meet their needs.

90. Their role will be to ensure that the voice, experience and knowledge of victims and survivors will integrally and authentically inform the programme and its products. This will increase its potential to improve mental and physical health outcomes and quality of life for people who have been victimised, and whose lives and life chances have been most adversely affected by this violence and abuse.

\section{Improving Outcomes for Individuals in Black and Minority Ethnic Communities}

91. The other measure of this programme's success will be the extent to which it can address the issues faced by black and minority ethnic women victims and survivors of domestic and sexual violence and abuse and their children, and to improve mental and physical health and quality of life outcomes for them. 
92. In this it will build on the work of the Home Office on forced marriage and 'honour crime', and the Home Office and Department of Health work on female genital mutilation (FGM) and trafficking for purposes of sexual exploitation. Key voluntary sector organisations such as Southall Black Sisters and FORWARD, will act as Specialist BME Advisers to the programme. The black and minority ethnic elements of the programme will also build on the NIMHE BME community engagement programme and the DH/NIMHE Action Plan Delivering Race Equality (2005). It will also be tied in with the work of the Department of Health on Health Equalities.

93. In this context the programme will focus on developing guidelines that include what is known about the nature, extent, effects and needs of $\mathrm{BME}$ women and children. What is produced by the programme will build on and be derived substantially from the work of BME voluntary sector organisations. One objective will be to ensure that what is known about the mental and physical health needs of BME women and children victims of domestic and sexual violence and abuse becomes part of the Department of Health's BME community engagement programme.

94. The objectives of the VVAPP programme will also be built into NIMHE's BME mental health programme, which itself is an important component of the Delivering Racial Equality (DRE) Action Plan.

\section{Improving Outcomes for Individuals with Physical and Learning Disabilities}

95. There is evidence that people with physical and learning disabilities are particularly vulnerable to physical and sexual abuse as children, adolescents and adults. ${ }^{42,43}$ Addressing their issues will be an important element of the VVAPP programme as part of the Delphi expert consultation, the service mapping and the experiential research on 'violence and abuse care pathways.' 


\section{A Whole System Approach to Support Improvements in Outcomes for Individuals and Organisations}

\section{Strategic Change framework}

96. The work of the VVAPP programme as set out in this document is the first stage in a much larger and longer process of supporting improvements in outcomes for individuals and organisations across sectors, services and settings including the criminal justice sector as set out in Figure 5.

Figure 5: Change Model

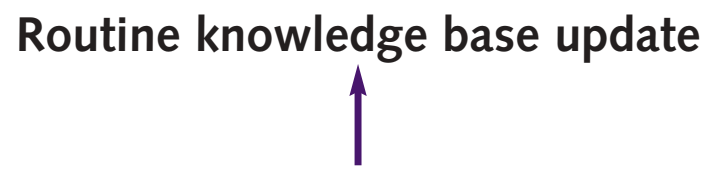

Service evaluation and outcomes for individuals

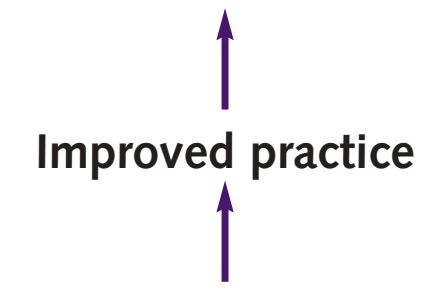

New ways of working<smiles>[CH]C</smiles>

Service planning, redesign and development

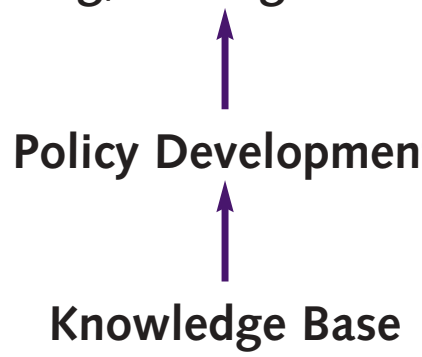

97. A framework for this whole system programme of strategic change (developed by Liz Mayne the co-author and architect of the Women's Mental Health Strategy) is set out in Annex B. It is structured in terms of aims and expected outcomes with activity required set out under each of the groups covered by the programme. 
98. There are six elements underpinning a whole system approach.

i. building on the evidence and knowledge base as outlined in this document.

ii. policy development at all levels, with the national policies outlined in this document developed into local policies and local planning processes

iii. the development of networks and alliances within and across sectors to raise awareness, inform policy development, improve practice and support service development.

iv. establishing an ethos of accountability that encourages all key stakeholders at all levels in whatever role or position, to recognise and fulfil their moral and ethical obligations to victims of domestic and sexual violence and abuse.

v. the provision of education and training to ensure that staff are able to identify and respond to the needs of victims, survivors and abusers

vi. service development and culture change in the statutory sectors, the mainstreaming of specialist services in the voluntary and independent sectors and a mutually responsive learning climate across the sectors.

\section{Stakeholder outcomes}

99. There are many stakeholders in this programme and each has a critical role to play. These include:

- $\quad$ service users: victims, survivors and abusers;

- $\quad$ service providers: statutory and voluntary/independent and criminal justice sectors;

- referrers: within eg health, social care, education, criminal justice system;

- commissioners: primarily Primary Care Trusts;

- Government departments: responsible for health, social care, education and the criminal justice system. 
- $\quad$ Royal Colleges, professional bodies and workforce organisations 100. For each of these stakeholder groups, there are specific outcomes intended through the implementation of this programme. These are:

For Victims, Survivors and Service Users (including Abusers) that they are:

- listened to, respected and empowered by the healing or reforming process;

- $\quad$ provided with the therapeutic tools to heal/recover (victims and survivors) or to reform (abusers) within a safe and validating environment;

- $\quad$ supported in dealing with the attendant social, economic and family realities of their lives;

- $\quad$ supported by the due legal process whenever appropriate;

- actively and genuinely involved in service development, monitoring and evaluation.

For Service Providers that they:

- $\quad$ receive the necessary support and resources to meet the needs of service users eg education and training, staff supervision and support, the means to sustain and extend their services (particularly relevant to the voluntary sector).

For Referrers that they:

- $\quad$ have access to the fullest information on the type and range of services available, quality assurance, admission criteria and cost in both the statutory and voluntary/independent sectors. 
For Commissioners that they:

- $\quad$ have access to the fullest information on what is required, the type and range of services available currently in the statutory and voluntary/independent sectors in order to assess need, identify gaps in provision and develop an appropriate commissioning strategy.

For Government Departments that they:

- $\quad$ receive relevant and appropriate data to develop integrated policies within their health, social care, education and criminal justice responsibilities to address the continuum of violence and abuse and it's impact on victims, survivors and abusers.

For Royal Colleges, Professional Bodies and Workforce Organisations that they:

- can support the education and development of their members

- can exercise a role in the governance and accountability of their members in meeting their obligations to victims of domestic and sexual violence and abuse. 


\section{Conclusion}

\section{Victims of violence and abuse prevention programme deliverables}

101. There are a number of key deliverables intended to arise out of the implementation of this programme for each group of stakeholders to support the achievement of the specified outcomes for individuals and organisations. These are set out in boxes in Annex C covering:

- $\quad$ Service users (victims, survivors and abusers)

- $\quad$ Service providers - generic statutory services

- $\quad$ Service providers - specialist voluntary and independent sectors

- $\quad$ Referrers

- Commissioners

- Government departments

- $\quad$ Royal Colleges, professional bodies and workforce organisations

\section{Programme deliverables in year one - by April 2006}

\section{Publications}

- $\quad$ Tackling the Health and Mental Health Effects of Domestic and Sexual Violence and Abuse (Itzin, C. 2006) Joint Department of Health, National Institute for Mental Health in England and Home Office Victims of Violence and Abuse Prevention Programme Implementation Guide

- National Guidelines for the Development of Sexual Assault Referral Centres (SARCs) (2005) Home Office jointly with the Department of Health and NIMHE

- $\quad$ The Needs of Young People Who Display Sexually Harmful Behaviours and the Effectiveness of Interventions and Service Approaches to Meet These Needs and to Prevent Sexually Abusive and Criminal Behaviour (Whittle, N., Bailey, S., and 
Kurtz, Z. 2006) Department of Health and NIMHE jointly with the Home Office

- Domestic Violence Handbook for Mental Health Practitioners (Agnew- Davis, R. (2006)

- A National Strategy for Young People Who Sexually Abuse (2006) Department of Health jointly with the Home Office

\section{Research Reports}

- Delphi Expert Consultation Round 1 Findings Report

- Sexual and Domestic Violence and Abuse Voluntary, Independent and Criminal Justice System Service Mapping Report

\section{Outcomes for individuals - in five years}

102. Benchmarks will be identified for organisations to monitor the impact of the programme on improving practice and outcomes for individuals measured by what will be better for victims and survivors of domestic and sexual violence and abuse in five years time against each of the programme's objectives:

- $\quad$ reducing the mental illness, self harm, suicide and physical injury associated with victimisation;

- increasing safety and minimising revictimisation;

- $\quad$ improving the quality of life of victims and survivors; and

- where possible preventing continued and new offending, through early and effective interventions with abusers in both the criminal justice system and the community.

\section{Stakeholder participation}

103. The VVAPP programme provides a real opportunity for everyone in each of the areas covered by the programme across the sectors and throughout the whole of the system with something to contribute, to build on what they have done and participate in taking this work forward. 


\section{Annex A: Programme Team}

\section{Core Team}

Programme Director

Research Management

Research Associate

Programme Administrator
Professor Catherine Itzin

Professor Ann Taket

Dr. Silvie Dresselhaus

Stephanie Gray

\section{Consultants}

Research Director

Outcomes Research Adviser

Public Health Adviser

Women's Mental Health

Project Management

\author{
Professor Marianne Hester \\ Professor Jalna Hanmer \\ Dr. Jo Nurse \\ Liz Mayne \\ Mark Johnson/Sue Salas \\ (Mental Health Strategies)
}

\section{Acknowledgements:}

A number of individuals have supported the development of the programme:

Dr. Roxane Agnew-Davies - Programme Development

Dr Jackie Barron - Research Methodolgy Development

Dr Silvie Dresselhaus - Research Methodology Development Support

Rima Chowdury-Hawkins - Programme Support

Professor Gene Feder - Research Methodology Development

Gillian Finch - Programme Development

Stephanie Gray - Programme Administration

Nicola Harwin - Programme Development

Emily Hall - Programme Support

Chris Holley - Programme Development

Deborah Jamieson - Policy Development

Christine Mann - Programme Development

Liz Mayne - Developing the Framework and Programme Deliverables (Annexes B \&C); 
Dr Jo Nurse - Life Course Perspective Diagram Emily Popler - Programme Support

Dr. Lorraine Radford- Research Methodolgy Development Stephanie Stuart - Programme Support

\section{About the author}

Professor Catherine Itzin (BA, MPhil, PhD, FRSA) is Director of the joint Department of Health and NIMHE Victims of Violence and Abuse Prevention Programme (VVAPP) and the Department of Health adult mental health policy lead for domestic and sexual violence and abuse. She holds a chair as Professor of Mental Health Policy at the University of Lincoln, and is the Violence Abuse and Mental Health Programme Lead in the Centre for Clinical and Academic Workforce Innovation (CCAWI) at Lincoln University.

\section{Joint Department of Health and NIMHE Victims of Violence and Abuse Programme (VVAPP) \\ Expert Advisers List}

\section{Expert Groups}

Adults Sexually Victimised in Childhood Expert Group (AcsaEG)

Gillian Finch (co-chair) - Chair of The Survivors Trust and Coordinator of CIS'ters

Chris Holley (co-chair) - Consultant Nurse on Sexual Abuse, Staffordshire NHS Trust

Dr Jonathan Bird - Chair of Trustees, NAPAC

Detective Sergeant Sue Bufton - Child Protection Team, Staffordshire Police

Ann Byrne - Chief Executive of The Women's Therapy Centre Lee Eggleston - Rape Crisis Co-ordination Group (England and Wales)

Dr Carol Ann Hooper - Lecturer in Social Policy, University of York, with research interests in child sexual abuse. 
Ann Jackson- Senior practice development fellow mental health for the Royal College of Nursing and Programme manager - women's mental health - women's team \& Juvenille group - prison service.

Lynne Jordan- Chartered Counselling Psychologist in Adult Mental Health NHS West Sussex; Director of Jordan Counselling, Independent Trainer and Supervisor.

Kathryn Livingston - Chairperson of First Person Plural

Dr Fiona Mason - Consultant Forensic Psychiatrist, St Andrews Hospital

Fay Maxted - Co-ordinator of The Survivors Trust

Comfort Momoh - FGM/ Public Health Specialist, St Thomas Hospital

Dr Sarah Nelson - Child Sexual Abuse Researcher Edinburgh University Maria Jahan Paimany - Home Office Victims Advisory Panel Lay Member

Peter Saunders - Director of National Association of People Abused in Childhood

Sally Scattergood - specialist working with Adult Survivors of Child Sexual Assault

Jackie Sharratt - Specialist Nurse on Sexual Abuse Wolverhampton City NHS-PCT

Moira Walker - Clinician with Dorset Relate, Bournemouth University

Ian Warwick - Specialist on Sexually Abused Males University of Huddersfield

Gilli Watson - Clinical Psychologist University of Plymouth

Sam Evans - OCJR Victims \& Confidence Unit, Home Office

Liz Mayne - Department of Health and National Institute of Mental Health for England Lead for Women's Mental Health 
Domestic Violence Expert Group (DVEG)

Nicola Harwin CBE (Chair) - Chief Executive Women's Aid Federation of England

Dr Roxane Agnew-Davies - Clinical Psychologist, Senior Research Fellow at South Bank University

Rachel Carter Assistant Director Greater London Domestic Violence Project

Jane Andreson - Senior Counsellor \& Project Manager, The Maya Centre

David Bartlett - Services Manager, Fathers Direct

Prof. Gene Feder - General practitioner and professor of primary care research and development, Queen Mary University of London

Dr Aisha Gill - Senior Lecturer in Criminology, Roehampton University Ann Hamilton - Trustee of Zero Tolerance Charitable Trust

Dr Cathy Humphreys - Reader and Researche, Violence Against Women, University of Warwick

Pauline Magowen -Independent Researcher and Specialist on Domestic Violence and Disability

Geraldine Mason - Mental Health Development Officer, Greater London Domestic Violence Project

Dr. Melanie McCarry, Violence Against Women Research Group, Centre for Family Policy and Child Welfare, University of Bristol Dr. Gillian Mezey - Reader \& Consultant in Forensic Psychiatry St. George's, University of London

Jan Pickles - Director of Cardiff Women's Safety Unit

Dr Amanda Robinson - Criminology and Criminal Justice, Cardiff University

Hannanah Siddiqui - Co-ordinator and Policy Worker, Southall Black Sisters 
Prof. Betsy Stanko -Metropolitan Police, Senior Advisor - Strategic Analysis and affiliated to Royal Holloway, University of London

Dr Imogen Stephens - Director of Public Health, Western Sussex PCT Prof. Ann Taket - Health Services Research London South Bank University

Dr Ravi Thiara - Senior Research Fellow Violence Against Women, University of Warwick

Jo Todd - Director of RESPECT Association for domestic violence perpetrator programmes and associated support services Deborah Jamieson- Domestic Violence Policy Lead, Home Office Christine Mann - National Domestic Violence Co-ordinator, Department of Health

Lisa Westall - Department of Health Domestic Violence Health Policy Lead

Child Victims of Domestic Violence and Sexual Abuse Expert Group

\section{Dr Jean Price (Chair) - Community Paediatrician Southampton City PCT}

Ruth Aitken - Independent Psychologist and Policy Advisor to Refuge

Detective Chief Inspector lan Angus- Child Abuse Investigation Command, Metropolitan Police

Heather Bacon - Consultant Clinical Psychologist, Specialist Post, Child Protection.

Dr Anne Bannister - Child Psychotherapist/ Child Sexual Abuse Consultant

Mary Baginsky - Senior Research Officer, NSPCC

Dorit Braun - Chief Executive of Parentline Plus

Dr Ann Cattanach -free-lance child care consultant therapist, teaching fellow, University of York, staff member virtual faculty, Fairleigh Dickinson University, New Jersey. 
Dorian Cole - Nurse Consultant - Child Protection, Haringey TPCT Chelsea Bonehill - CAFCASS

Carol Easton - Director of Childline

Prof. Elaine Farmer - Professor Elaine Farmer, Head, Centre for Family Policy and Child Welfare, University of Bristol

Donald Findlater - Deputy Director of The Lucy Faithfull Foundation Detective Chief Inspector Martin Fotheringham - Child Abuse Investigation Unit, Hampshire Police

Dr Chris Hobbs - Consultant Paediatrician, Leeds Teaching Hospital NHS Trust

Norma Howes -Forensic Psychologist, Specialist in Domestic Violence \& CSA

Kate Iwi - Children's Services Manager, Safe Contact Service, DVIP Hammersmith

Adwoa Kwateng-kluvitse - Director of FORWARD (Foundation for Women's Health, Research and Development) campaigning against FGM and Child Marriages Development) campaigning against FGM and Child Marriages

Dr. Mary Macleod - Chief Executive of National Family and Parenting Institute

Peter Newell - Coordinator of "Children are Unbeatable" Allience Jonathan Picken - Chair of British Association for the Study and Prevention of Child Abuse and Neglect (BASPCAN)

Ann Potter -Children's Services Manager, Barnardos

Bernie Ryan - Service Manager of St. Mary's SARC Manchester

Hilary Saunders - Children's Policy Officer, Women's Aid Federation England

Dr. June Statham - Thomas Coram Research Unit

Christine Humphrey -Department of Health Child Protection Policy Lead 
Adult Victims of Rape and Sexual Assault Expert Group (RSAEG)

Nicole Westmarland (Chair) - Research associate in the area of Gender and Violence, Research Associate in Gender and Violence, University of Bristol

Rima Chowdhury Hawkins - Amethyst Project Manager (SARCs for Children)

Sheila Coates - Director of South Essex Rape and Incest Counselling Crisis Centre (SERICC)

Angie Conroy - Co-ordinator of Colchester Rape Crisis

Detective Chief Superintendent Dave Gee - Derbyshire Police

Dr Helen Jones - Department of Criminology, Manchester Metropolitan University

Jo Lovett - Research Officer, Child and Woman Abuse Studies Unit, London Metropolitan University

Denise Marshall - Chief Executive of Eaves Housing for Women

Caz Minter-Wright - Chief Executive of Crisis Point, Walsall Rowan Centre (SARC)

Detective Chief Inspector Catherine Thundercloud - Lancashire Police

Dr Jan Welch - Clinical Director, The Haven SARC, Camberwell

Cath White - Clinical Director St Mary's SARC Manchester

Philip Rumney - Specialist on Male Rape, Sheffield Hallam University

Safina Siddique - Co-ordinator of Tyneside Rape Crisis

Martyn Sullivan - National Resource Co-ordinator of Survivors UK

Professor Jennifer Temkin University of Sussex Law School

Tanya Von Ahlefeldt - Home Office Victims Advisory Panel Lay Member

Helen Musgrove - Sexual Crime Reduction Team, Home Office 
Adolescent and Adult Sexual Abusers/Offenders Expert Group (SOEG) Bob McDonald (Chair) - Senior Policy Advisor, Department of Health Dr Susan Bailey -Consultant Child and Adolescent Forensic Psychiatrist, Registrar Royal College of Psychiatrists

Professor Anthony Beech - Forensic Psychologist, University of Birmingham

Jon Brown - Chair of National Organisation for the Treatment of Abusers (NOTA)

Jackie Craissati - Head of Forensic Clinical Psychology Service, Oxleas NHS Trust

Hilary Eldridge - Director Lucy Faithfull Foundation

Marcus Erooga - Area Children's Services Manager, NSPCC

Kevin Gibbs - , Area Children's Services Manager, NSPCC

Prof. Don Grubin - Professor of Forensic Psychiatry, Newcastle University. Newcastle, North Tyneside, Northumberland Mental Health Trust

Professor Simon Hackett - Specialist in Children and Young People Who

Sexually Abuse. Chair in Child Welfare, University of Luton. Editor of the Journal of Sexual Aggression.

Dr Zarrina Kurtz- Freelance Consultant in Public Health and Health Policy

Prof Tony Maden - Professor of Forensic Psychiatry, Imperial College London (and clinical director of services for dangerous and severe personality disorder at WLMHT).

Bobbie Print - Service Director Greater Manchester Adolescent Programme (YPSA)

Jonathan Vince Psychological treatment of Adults, NHS

Dr Eileen Vizard - Consultant Child and Adolescent Psychiatrist, Clinical Director of Young Abusers Project 
Kimberley Bingham/Nicky Mills - Juvenile Offenders Unit, Home Office

Liz Hill/Elizabeth Hayes - Public Protection and Courts Unit, Home Office

Dr. Bob Jezzard - Senior Medical Adviser for Child and Adolescent Mental Health Services, Department of Health

Prostitution, Pornography and Trafficking Expert Group

Professor Catherine Itzin (Chair) VVAPP programme director, Professor of Mental Health Policy Lincoln University

Chris Atkinson - Policy Adviser, Child Sexual Exploitation, NSPCC Jane Ayres - Outreach Service Manager, Praed Street Project- incl Sexual Health

Chris Beddoe - Director of ECPAT UK, End Child prostitution, pornography and trafficking

Natalia Dawkins - The Poppy Project Manager, Eaves Housing for Women

Kathy Evans - Strategy Director, Children's Society

Kathy French- Royall College of Nursing

Professor Jalna Hanmer - University of Sunderland, School of Health and Social Sciences Professor Marianne Hester - Centre for Family Policy and Child Welfare, School for Policy Studies, University of Bristol

Professor Liz Kelly - Director Child and Woman Abuse Studies Unit, London Metropolitan University

Sallie.McArdell - Project Sapphire, Metropolitan Police

Tink Palmer, Director, Stop it Now! UK \& Ireland

Jenny Pearce - Co-ordinator National Working Group on Sexually

Exploited Young People \& Chair of the Social Sciences Academic

Group, Middlesex University

Ethel Quayle - COPINE Project University College Dublin 
Wendy Shepherd Children's Service Manager Barnardos SECOS project Middlesbrough

Professor Alec Spencer - Director, Rehabilitation and Care, Scottish Prison Service \& Department of Applied Social Science at Stirling University.

Ginny Wilkinson - Principal Policy and Practice Officer (Child Sexual Exploitation), Barnardo's

Sue Jago - Head of the Prostitution Strategy Implementation Team, Criminal Law Policy Unit, Home Office

Specialist Advisers

Dr. Roxane Agnew-Davies- Clinical Psychologist, Senior Research Fellow, South Bank University

Professor John Ashton Regional Director of Public Health NW Region Chris Atkinson- Policy Adviser, Child Sexual Exploitation, NSPCC Professor Sue Bailey - Consultant Child \& Adolescent Forensic Psychiatrist, Chair of Child and Adolescent Faculty Royal College of Psychiatrists

Dr. Jackie Barron - Senior Research Officer Women's Aid

Professor Arnon Bentovim - Consultant Child \& Adolescent Psychiatrist Institute of Child Health

Rima Chowdhury-Hawkins Project Amethyst Manager (SARCs for Children)

Efua Dorkenoo- Independent Public Health specialist and women's health advocate.

Professors R. Emerson and Russell Dobash, Professors of Criminology University of Manchester

Hilary Eldridge - Director Lucy Faithfull Foundation

Professor Gene Feder - General practitioner and professor of primary care research and development, Queen Mary University of London 
Gillian Finch - Chair of The Survivors Trust and Co-ordinator of CIS'ters

Dr. Danya Glasser - Consultant Child and Adolescent Psychiatrist, Great Ormond St. Hospital

Professor Jalna Hanmer - University of Sunderland, International Centre for the Study of Violence \& Abuse

Professor Marianne Hester - Centre for Family Policy and Child Welfare, School for Policy Studies, University of Bristol

Professor Simon Hackett- Specialist in Young People Who Sexually Abuse, Institute of Applied Social Research, University of Luton

Nicola Harwin CBE - Chief Executive Women's Aid Federation of England

Chris Holley - Consultant Nurse on Sexual Abuse, Staffordshire NHS Trust

Baroness Howarth - Deputy Chair of CAFCASS, Patron Stop It Now

Professor Liz Kelly - Director of Child and Woman Abuse Studies Unit, London Metropolitan University

Baroness Kennedy QC Expert on domestic violence prosecutions

Dr. Zarinna Kurtz- Independent/Freelance Consultant in Public Health

Dr. Mary Macleod-Chief Executive of National Family and Parenting Institute

Christine Mann - National Domestic Violence Co-ordinator, Department of Health

Liz Mayne NIMHE Women's Mental Health Strategy Implementation lead

Dr. Gillian Mezey - Reader \& Consultant in Forensic Psychiatry St.

George's, University of London

Dr. Andrew McCulloch Director Mental Health Foundation

David Middleton- Head of Sex Offender Strategy and Programmes

Public Protection \& Licensed Release Unit, NOMS/NPD 
Dr. Jo Nurse Consultant in Public Health, Department of Health Government Office for the South East

Professor Susie Orbach - Psychoherapist and Writer, London School of Economics

Tink Palmer Director Stop It Now

Professor Michael Rutter Institute of Psychiatry

Dr. Sara Scott - Principal Research Officer Barnardos

Professor David Sallah Professor of Mental Health, Wolverhampton University, Director fo the DH/NIMHE Delivering Race Equality programme

Hannanah Siddiqui - Co-ordinator and Policy Worker, Southall Black Sisters

Prof. Betsy Stanko -Metropolitan Police, Senior Advisor - Strategic Analysis and affiliated to Royal Holloway, University of London Jo Todd Director RESPECT (domestic violence perpetrators) Professor Sylvia Walby University of Leeds (author The Costs of Domestic Violence DTI 2004)

Dr. Nicole Westmarland - Chair National Rape Crisis Coordination Group, Research Associate Gender and Violence, University of Bristol Tanya Von Ahlfeldt - Home Office Victims Advisory Panel Lay Member 


\section{Annex B: Liz Mayne}

\section{A whole system strategic framework for su pporting improvements in outcomes for organisations and individuals}

\begin{tabular}{|c|c|c|c|c|c|c|c|}
\hline \multirow{3}{*}{ AIMS } & \multicolumn{6}{|c|}{ ACTIVITY - to be designed, developed and undertaken on the basis of the Whole System Model } & \multirow{2}{*}{ EXPECTED OUTCOMES } \\
\hline & $\begin{array}{l}\text { Adult Domestic } \\
\text { Violence } \\
\text { Victims, } \\
\text { Survivors and } \\
\text { Perpetrators }\end{array}$ & $\begin{array}{l}\text { Child Victims of } \\
\text { Domestic } \\
\text { Violence and } \\
\text { Child Sexual } \\
\text { Abuse }\end{array}$ & \begin{tabular}{|l} 
Adolescent \\
and Adult \\
Sexual \\
Abusers/ \\
Offenders
\end{tabular} & $\begin{array}{l}\text { Adult } \\
\text { Victims of } \\
\text { Rape and } \\
\text { Sexual } \\
\text { Assault }\end{array}$ & $\begin{array}{l}\text { Adult Survivors } \\
\text { of Child Sexual } \\
\text { Abuse }\end{array}$ & $\begin{array}{l}\text { All Victims of } \\
\text { Sexual } \\
\text { Exploitation }\end{array}$ & \\
\hline & \multicolumn{6}{|c|}{$\begin{array}{l}\text { Addressing the mental and physical health implications for individual children, adolescents and adults } \\
\text { across the spectrum of domestic and sexual violence and abuse }\end{array}$} & \\
\hline $\begin{array}{l}\text { Evidence Baselining } \\
\text { To build on existing } \\
\text { knowledge base as identified } \\
\text { in initial scoping exercise by } \\
\text { the collation and analysis of } \\
\text { all relevant data. } \\
\text { To develop consistent } \\
\text { mechanisms to continue to } \\
\text { access existing and new data } \\
\text { required, together with } \\
\text { regular updating. } \\
\text { To identify 'best practice' in } \\
\text { prevention and effectively } \\
\text { meeting the needs of } \\
\text { victims, survivors and their } \\
\text { abusers. } \\
\text { To highlight the 'journeys' of } \\
\text { victims, survivors and their } \\
\text { abusers. }\end{array}$ & \multicolumn{6}{|c|}{$\begin{array}{l}\text { - Initial scoping review of the literature across the five groups of victims, survivors and abusers } \\
\text { conducted to inform the development of DH policy and to establish the programme } \\
\text { - Systematic Literature Review - bring together existing research and literature from all relevant fields } \\
\text { into a mental health context } \\
\text { - Map existing specialist services (primarily) in the voluntary/independent sectors (both those providing } \\
\text { formal counselling/therapy and those that don't include formal mental health elements but are } \\
\text { responding to women/children in distress (eg Women's Aid). } \\
\text { - Identify 'best practice' - establishing, through the building of consensus amongst } \\
\text { professionals/clinicians and service users (primarily using the DELPHI methodology), 'best practice' in } \\
\text { terms of service models, individual/group therapies (ie creative, complementary and 'talking' } \\
\text { therapies) and support groups/networks. } \\
\text { - Process mapping - using a process mapping methodology, explore and define pathways with and for } \\
\text { individuals who are victims, survivors and abusers. These will highlight both individual's } \\
\text { positive/negative access and experience of services and the causal relationship between experience } \\
\text { of violence and abuse (as both victim/survivor and abuser) and mental ill health. } \\
\text { Intelligence gathering - bring together data already routinely collected (eg helplines) and commission } \\
\text { the collation of further data as required. }\end{array}$} & $\begin{array}{l}\text { An extended knowledge base of: } \\
-\quad \text { the nature and extent of violence and abuse; } \\
-\quad \text { it's effects and impact; } \\
\text { - } \quad \text { effective prevention and early intervention } \\
\text { the capacity of / demands placed on existing } \\
\text { services; } \\
\text { what individual groups need in order to heal / } \\
\text { recover/ reform; } \\
\text { 'best practice' ie service models, psychological } \\
\text { therapies and support groups/networks; } \\
\text { the 'journeys' that victims, survivors and their } \\
\text { abusers have experienced. } \\
\text { Comprehensive mapping of specialist services (primarily) } \\
\text { provided by the voluntary/ independent sector, for } \\
\text { subsequent mainstreaming. } \\
\text { A conducive context for mutual learning between the } \\
\text { voluntary/independent and statutory sectors. }\end{array}$ \\
\hline
\end{tabular}




\begin{tabular}{|c|c|c|c|c|c|c|c|}
\hline \multirow{3}{*}{ AIMS } & \multicolumn{6}{|c|}{ ACTIVITY - to be designed, developed and undertaken on the basis of the Whole System Model } & \multirow{2}{*}{ PROPOSED OUTCOMES } \\
\hline & $\begin{array}{l}\text { Adult Domestic } \\
\text { Violence } \\
\text { Victims, } \\
\text { Survivors and } \\
\text { Perpetrators }\end{array}$ & $\begin{array}{l}\text { Child Victims of } \\
\text { Domestic } \\
\text { Violence and } \\
\text { Child Sexual } \\
\text { Abuse }\end{array}$ & $\begin{array}{l}\text { Adolescent } \\
\text { and Adult } \\
\text { Sexual } \\
\text { Abusers/ } \\
\text { Offenders }\end{array}$ & \begin{tabular}{|l} 
Adult \\
Victims of \\
Rape and \\
Sexual \\
Assault
\end{tabular} & \begin{tabular}{|l} 
Adult Survivors \\
of Child Sexual \\
Abuse
\end{tabular} & \begin{tabular}{|l} 
All Victims of \\
Sexual \\
Exploitation
\end{tabular} & \\
\hline & \multicolumn{6}{|c|}{$\begin{array}{l}\text { Addressing the mental and physical health implications for individual children, adolescents and adults } \\
\text { across the spectrum of domestic and sexual violence and abuse }\end{array}$} & \\
\hline $\begin{array}{l}\text { Policy Development } \\
\text { To effect integrated policy } \\
\text { development across all } \\
\text { relevant areas eg health, } \\
\text { education, social care and } \\
\text { the criminal justice system to } \\
\text { ensure early prevention and } \\
\text { effective responses for } \\
\text { victims. } \\
\text { To devise the means by } \\
\text { which professionals/ services } \\
\text { - identifying and responding } \\
\text { to victims, survivors and } \\
\text { their abusers - are equipped } \\
\text { to deliver 'best practice' }\end{array}$ & \multicolumn{6}{|c|}{$\begin{array}{l}\text { - Identify groups of clinicians/services responding to the needs of victims, survivors and their abusers in } \\
\text { the statutory sector who need to be equipped to deliver 'best practice'; } \\
\text { - Produce guidance on 'best practice' for identified target groups based on the outputs of the literature } \\
\text { review, service mapping, service user mapping and DELPHI research. This can be used to inform the } \\
\text { Training/Education and Service Development/Redesign work areas. } \\
\text { - Consider the need for integrated policy development across all relevant areas ie health, education, } \\
\text { social care and the criminal justice system and work in partnership with appropriate government leads } \\
\text { in effecting this. }\end{array}$} & $\begin{array}{l}\text { Appropriate guidance to inform the development of a } \\
\text { responsive learning climate for increasing individual and } \\
\text { organisational awareness, improving practice and related } \\
\text { service development and redesign. } \\
\text { Proposals will be developed to facilitate integrated } \\
\text { policy development across all relevant areas. }\end{array}$ \\
\hline
\end{tabular}




\begin{tabular}{|c|c|c|c|c|c|c|c|}
\hline \multirow{3}{*}{ AIMS } & \multicolumn{6}{|c|}{ ACTIVITY - to be designed, developed and undertaken on the basis of the Whole System Model } & \multirow{2}{*}{ EXPECTED OUTCOMES } \\
\hline & $\begin{array}{l}\text { Adult Domestic } \\
\text { Violence } \\
\text { Victims, } \\
\text { Survivors and } \\
\text { Perpetrators }\end{array}$ & $\begin{array}{l}\text { Child Victims } \\
\text { of Domestic } \\
\text { Violence and } \\
\text { Child Sexual } \\
\text { Abuse }\end{array}$ & $\begin{array}{l}\text { Adolescent and } \\
\text { Adult Sexual } \\
\text { Abusers/ } \\
\text { Offenders }\end{array}$ & $\begin{array}{l}\text { Adult Victims } \\
\text { of Rape and } \\
\text { Sexual Assault }\end{array}$ & $\begin{array}{l}\text { Adult } \\
\text { Survivors } \\
\text { of Child } \\
\text { Sexual } \\
\text { Abuse }\end{array}$ & $\begin{array}{l}\text { All Victims of } \\
\text { Sexual } \\
\text { Exploitation }\end{array}$ & \\
\hline & \multicolumn{6}{|c|}{$\begin{array}{l}\text { Addressing the mental and physical health implications for individual children, adolescents and adults } \\
\text { across the spectrum of domestic and sexual violence and abuse }\end{array}$} & \\
\hline $\begin{array}{l}\text { Networks \& Alliances } \\
\text { To identify and engage with } \\
\text { relevant networks and } \\
\text { alliances that can be } \\
\text { influential/require } \\
\text { influencing, } \\
\text { To identify ways of ensuring } \\
\text { an ongoing interface with } \\
\text { service users which is } \\
\text { integral and authentic in } \\
\text { character. }\end{array}$ & \multicolumn{6}{|c|}{$\begin{array}{l}\text { - Identify existing networks and alliances - that can be influential or require influencing - within and } \\
\text { across all relevant sectors at strategic and operational levels. } \\
\text { - Devise a means of ensuring their involvement with, and contribution to, the programme and identify } \\
\text { their appropriate roles. } \\
\text { - Identify gaps and, if necessary, develop new networks and alliances. } \\
\text { - Ensure that the voice and experience of victims, survivors and their abusers authentically inform all of } \\
\text { the programme's work areas. }\end{array}$} & $\begin{array}{l}\text { Effective networking within and across all relevant } \\
\text { sectors in order to meet the core objectives of the } \\
\text { programme ie to raise awareness; inform policy } \\
\text { development; improve practice; support service } \\
\text { development/redesign. }\end{array}$ \\
\hline
\end{tabular}




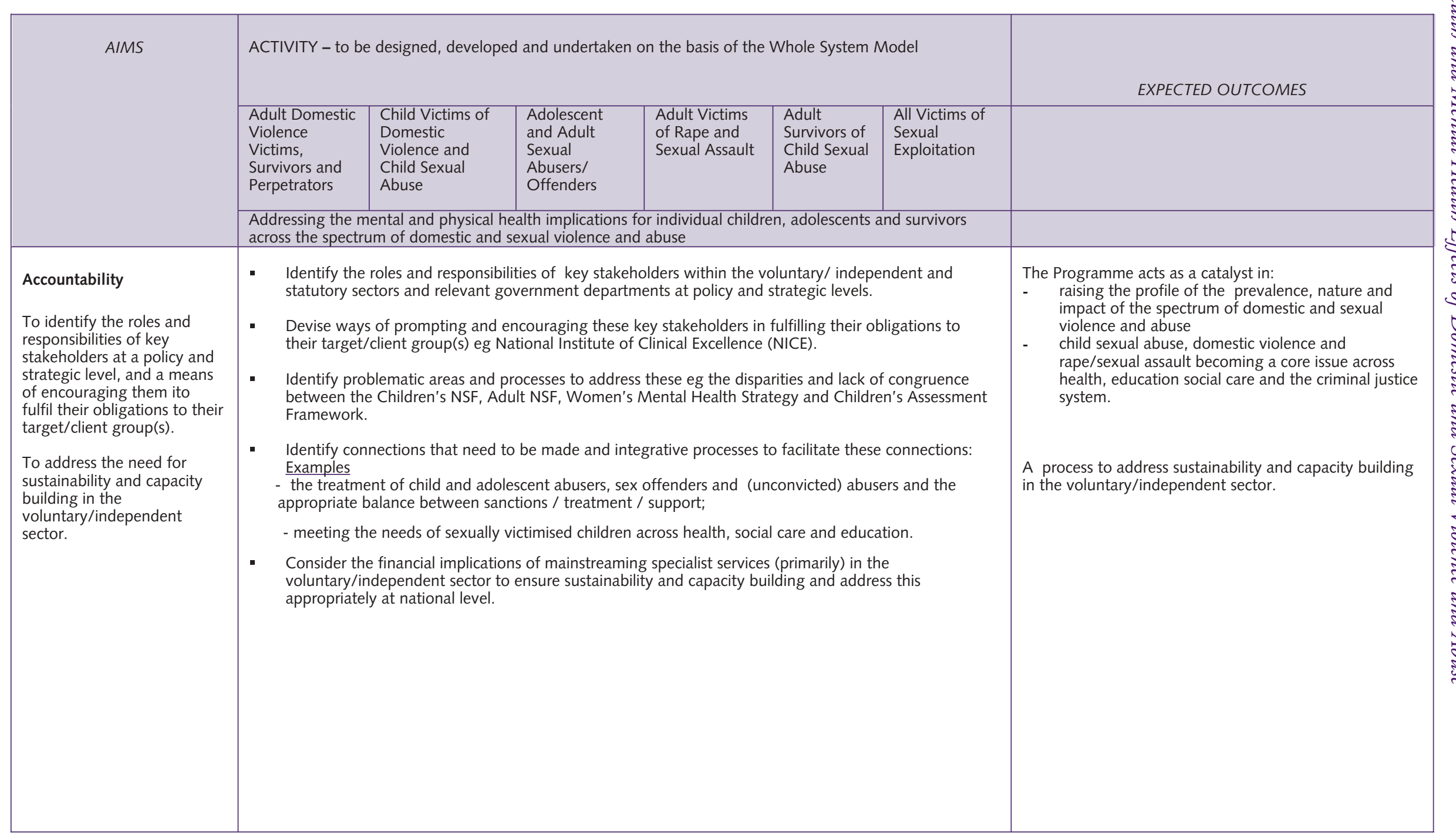




\begin{tabular}{|c|c|c|c|c|c|c|c|}
\hline \multirow[t]{3}{*}{ AIMS } & \multicolumn{6}{|c|}{ ACTIVITY - to be designed, developed and undertaken on the basis of the Whole System Model } & \multirow{2}{*}{ EXPECTED OUTCOMES } \\
\hline & $\begin{array}{l}\text { Adult Domestic } \\
\text { Violence } \\
\text { Victims, } \\
\text { Survivors and } \\
\text { Perpetrators }\end{array}$ & $\begin{array}{l}\text { Child Victims of } \\
\text { Domestic } \\
\text { Violence and } \\
\text { Child Sexual } \\
\text { Abuse }\end{array}$ & $\begin{array}{l}\text { Adolescent } \\
\text { and Adult } \\
\text { Sexual } \\
\text { Abusers/ } \\
\text { Offenders }\end{array}$ & $\begin{array}{l}\text { Adult Victims } \\
\text { of Rape and } \\
\text { Sexual Assault }\end{array}$ & $\begin{array}{l}\text { Adult } \\
\text { Survivors of } \\
\text { Child Sexual } \\
\text { Abuse }\end{array}$ & $\begin{array}{l}\text { All victims of } \\
\text { Sexual } \\
\text { Exploitation }\end{array}$ & \\
\hline & \multicolumn{6}{|c|}{$\begin{array}{l}\text { Addressing the mental and physical health implications for individual children, adolescents and survivors } \\
\text { across the spectrum of domestic and sexual violence and abuse }\end{array}$} & \\
\hline $\begin{array}{l}\text { Education and Training } \\
\text { To develop the means of } \\
\text { educating and training } \\
\text { Professionals/services in } \\
\text { prevention of abuse and in } \\
\text { identifying and responding } \\
\text { to the needs of victims, } \\
\text { survivors and their abusers. }\end{array}$ & \multicolumn{6}{|c|}{$\begin{array}{l}\text { - Identify groups of professionals/services responsible for delivering 'best practice to victims, survivors } \\
\text { and their abusers. } \\
\text { - Identify the skills and competencies they require in order to deliver 'best practice. } \\
\text { - Working on a partnership basis with all key stakeholders, devise the means of developing and } \\
\text { delivering appropriate education and training at national and regional level. } \\
\text { - As part of this process, consider the important role of pilotting and evaluating new } \\
\text { forms of education and training. }\end{array}$} & $\begin{array}{l}\text { Professionals/services will have access to appropriate } \\
\text { education and training to facilitate the delivery of 'best } \\
\text { practice' to effectively meet the needs of victims, } \\
\text { survivors and their abusers. }\end{array}$ \\
\hline
\end{tabular}




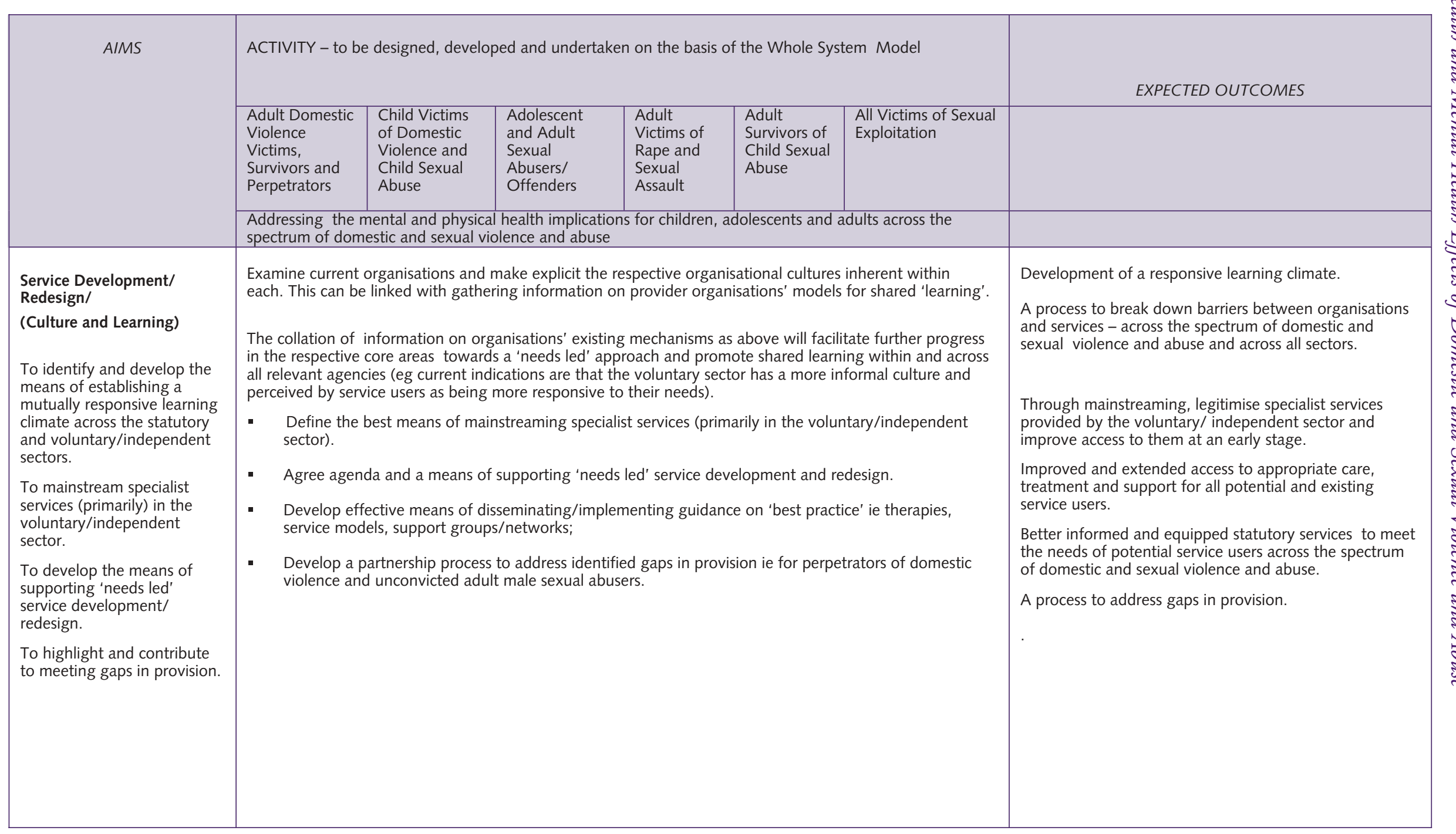




\section{Annex C: Victims of Violence and Abuse Prevention Programme Deliverables}

\section{Liz Mayne}

\section{Service Users}

Access to safe services ie those that provide both physical and psychological safety - at the earliest stage possible - that enable them to:

i) disclose the violence and abuse that they have experienced or perpetrated (in relation to 'unconvicted' male abusers and perpetrators of domestic violence);

ii) recover/heal (victims/survivors) within an environment that is validating, supportive and non-judgemental, or reform (abusers) in settings that provides specific and appropriate individual/group therapies and support groups/networks for the requisite period of time.

iii) improve the social, economic and/or family context of their lives eg access to safe and supportive accommodation, education, training and employment opportunities; help with joining social and community networks to reduce their social isolation; tangible support in their parenting role (as appropriate);

iv) deal with legal processes (as and when appropriate) eg supporting a woman victim of domestic violence in giving evidence in court against her male perpetrator, or a woman survivor of child sexual abuse in providing a police statement to inform the prosecution of her abuser.

v) input, in a comfortable and confidential manner, to both the monitoring and evaluation of the service they are in receipt of and to subsequent remedial action, if required eg receive written information on the service's formal processes and procedures to achieve this. 


\section{Service Providers - Statutory Services (generic)}

Access to:

i) Evidence and intelligence, gathered by the programme, to raise their awareness and knowledge of the:

- $\quad$ revalence, high incidence and nature of violence and abuse, and its impact on the mental health of victims, survivors and of abusers.;

- intergenerational factors associated with violence and abuse' eg for girls, the predisposition following sexual abuse as a child to be vulnerable to revictimisation as adolescent and adult survivors; the links for some boys between having been sexually abused as a child and becoming adolescent and adult child sexual abusers;

ii) Collate and disseminate evidence of effective programmes for the early prevention of abuse, and identification of high risk groups for experiencing or perpetrating abuse for early intervention

- Develop integrated inter-governmental, service provider and voluntary agency models to maximise prevention and early intervention

iii) Information outlining the pathways of individuals, who are victims, survivors and abusers, gathered by the programme using a process mapping methodology, to raise their awareness and knowledge of the:

- cycles and continuum of violence and abuse;

- positive and negative experiences of/outcomes for victims, survivors and abusers and what factors differentiate the 'positive' and 'negative';

- $\quad$ respective current roles of the voluntary/independent sectors ie breadth of specialist services and statutory sectors ie current paucity of care and support. 
iii) National mapping and mainstreaming of specialist services in the voluntary sector, undertaken by the programme so that they are aware of which services exist in their area in order to:

- make referrals if and when appropriate/provide this information to their service users;

- $\quad$ work with specialist voluntary providers eg in the development and delivery of staff training and appropriate psychological therapies within statutory services.

iv) National service guidelines covering effective service models, psychological therapies and support groups/networks to inform a responsive learning climate and establish a needs-led service.

v) Appropriate training to effectively work with and meet the needs of victims, survivors and abuser.

\section{Service Providers - Voluntary/Independent Sectors (specialist)}

Recognition of the essential and valuable role they play in the provision of specialist services for victims, survivors and abusers through the:

i) Mapping and mainstreaming of their services across the (generic) statutory sector.

ii) Opportunity to work in partnership with statutory sector (generic) providers to:

- $\quad$ share their expertise, knowledge and understanding of the needs of victims, survivors and abusers eg input to staff training; development and delivery of appropriate psychological therapies in statutory sector services.

- $\quad$ maximise access by victims, survivors and abusers to their specialist services.

iii) Receipt of adequate statutory funding to ensure their financial stability, sustainability and capacity building to meet the anticipated increased demand for their services. 
iv) Assistance from statutory commissioners in meeting the requirements of service level agreements eg robust accounting, monitoring and evaluation procedures.

\section{Referrers}

Access to:

i) and ii) above (see Service Providers: Generic Statutory Services)

ii) National mapping of specialist services in the voluntary/independent sector so that they are aware of the range of services that exist inside and outside their area for potential referral purposes.

iv) Relevant information in order to make an informed and appropriate referral to an individual service eg locality, admission/exclusion criteria, cost per place/bed, length of stay, operational and clinical policies, outcome of monitoring and evaluation processes.

\section{Commissioners}

Access to:

i) and ii) above (see Service Providers: Generic Statutory Services)

iii) Mapping of specialist services in the voluntary sector so that they are aware of which specialist services exist in their locality in order to:

- $\quad$ assess the appropriateness of formally commissioning existing services to meet the mental health care needs of victims, survivors and abusers locally;

- identify current gaps in provision and, if necessary, commission additional services.

iv) National service guidelines covering ie effective service models, psychological therapies, support groups/networks to inform their commissioning process. 


\section{Government Departments (Across Health, Social Care, Education And Criminal Justice)}

Access to:

i) and ii) above (see Service Providers - Generic Statutory Services)

iii) National mapping of specialist services in the voluntary sector so that they;

- $\quad$ are aware of current national coverage;

- $\quad$ can identify gaps in specialist services and develop a strategy to address these gaps at national level.

iv) National service guidelines covering ie effective service models, psychological therapies and support groups/networks to develop required new national policy and the means of implementation. 


\section{References}

Barron, J. (2004a) Health and Domestic Violence: Two Years on Survey 2002-2003 Bristol: Women's Aid

Barron, J. (2004b) Struggle to Survive: Challenges for Delivery of Services on Mental Health, Substance Misuse and Domestic Violence - Report of Findings of Survey 2002-2004 Bristol: Women's Aid

Bolen, R.M., Russell, D.E.H. (2000) 'Child Sexual Abuse Prevalence: A Review and Re-analysis of Relevant Studies' in Itzin, C. (ed) op cit. 169-197

Bradley, F., Smith, M., Long, J., and O'Dowd, T., (2002) ‘Reported Frequency of Domestic Violence: Cross-Sectional Survey of Women Attending General Practice' British Medical Journal 324, 2 February 271-274

Briere, J. and Runtz, M. (1988) 'Symptomatology Associated with Childhood Victimisation in a Nonclinical Adult Sample' Child Abuse and Neglect 12 51-59

British Medical Association (1998) Domestic Violence: A Healthcare Issue London: BMA

Cawson, P., Wattam, C., Brooker, S. and Kelly, G. (2000) Child Maltreatment in the UK: A Study of Prevalence of Child Abuse and Neglect London: NSPCC

Department for Education and Skills (2003) Every Child Matters Green Paper London: DfES

Department for Education and Skills (2004) Every Child Matters: The Next Steps London: DfES

Department of Education and Skills (2006) Working Together to Safeguard Children: A Guide to Inter-Agency Working to Safeguard and Promote the Welfare of Children London: DfES with the Department of Health 
Department of Health (1999a) Mental Health National Service Framework: Modern Standards and Service Models London:

Department of Health

Department of Health (1999b) Working Together to Safeguard Children: A Guide to Inter-Agency Working to Safeguard and Promote the Welfare of Children London: Department of Health, Home Office, Department of Education and Employment

Department of Health (2000a) Framework for the Assessment of Children in Need and their Families London: Department of Health, Home Office, Department of Education and Employment

Department of Health (2000b) Domestic Violence: A Resource Manual for Health Professionals London: Department of Health

Department of Health (2001) The National Suicide Prevention Strategy for England London: Department of Health

Department of Health (2002) Women's Mental Health: Into the Mainstream - Strategic Development of Mental Health Care for Women London: Department of Health

Department of Health (2003a) Mainstreaming Gender and Women's Mental Health - Implementation Guidance London: Department of Health

Department of Health (2003b) Personality Disorder: No Longer a Diagnosis of Exclusion (2003b) London: Department of Health

Department of Health (2003c) Tackling Health Inequalities: A Programme for Action London: Department of Health

Department of Health (2004a) National Service Framework for Children, Young People and Maternity London: Department of Health, Department for Education and Skills

Department of Health (2004b) NSF for Children, Young People and Maternity - Supporting Local Delivery London: Department of Health, Department for Education and Skills

Department of Health (2004c) From Here to Equality: A Strategic Plan to Tackle Stigma and Discrimination on Mental Health Grounds London: Department of Health 
Department of Health (2004d) Choosing Health: Making Healthy Choices Easier London: Department of Health

Department of Health (2005) Delivering Choosing Health: Making Healthy Choices Easier London: Department of Health

Department of Trade and Industry (2003) Delivering Gender Equality London: DTI

Finkelhor, D. (1994) 'Current Information on the Scope and Nature of Child Sexual Abuse' The Future of Children: Sexual Abuse of Children 4.2 31-53

Finkelhor, D. (1995) 'The Victimisation of Children: A Developmental Perspective' American Journal of Orthopsychiatry 65 (2) 177-193

Golding, J.M. (1999) 'Intimate Partner Violence as a risk factor for mental disorders: A Meta-Analysis' Journal of Family Violence 14, 2, 99-132

Hall, D. and Lynch, M. A. (1998) 'Violence Begins at Home' British Medical Journal 316 1551-1560

Hanmer, J. (2000) Domestic Violence and Gender Relations: Contexts and Connections in Hanmer, J. and Itzin, op cit 9-23

Hanmer, J. and Itzin, C. (2000) Home Truths About Domestic Violence London: Routledge

Her Majesty's Treasury (2004) Child Poverty Review London:HMT Hester, M., Pearson, C., and Harwin, N. (2000) Making an Impact: Children and Domestic Violence. A Reader London: Jessica Kingsley Hollins, S. and Hollins, M. (2005) You and Your Child: Making Sense of Learning Disabilities London: KARNAC

Home Office (2003a) Safety and Justice: Consultation on Domestic Violence London: Home Office

Home Office (2003b) A New Deal for Victims and Witnesses: National Strategy to Deliver Improved Services London: Home Office Home Office (2004) Paying the Price: A Consultation Paper on Prostitution London: Home Office 
Home Office (2006) A Coordinated Prostitution Strategy and a summary of responses to Paying the Price London: Home Office Humphreys, C. and Thiara, R. (2003) 'Mental Health and Domestic Violence: 'I Call It Symptoms of Abuse' British Journal of Social Work 33 209-226

Itzin, C. (2000) Home Truths About Child Sexual Abuse London: Routledge

Itzin, C. (2000) 'Child Protection and Child Sexual Abuse Prevention: Influencing Policy and Practice' in Itzin, C. (ed) Home Truths About Child Sexual Abuse London: Routledge 405-449

Kendall-Tackett, K.A., Williams, L.M., and Finkelhor, D. (1993) 'Impact of Sexual Abuse of Children: A Review and Synthesis of Recent Empirical Studies' Psychological Bulletin 113 164-180

Kennedy, M. (1996) 'Sexual Abuse and Disabled Children' in Encounters with Strangers - Feminism and Disability (ed) Morris, J. London: The Women's Press

Kershaw, C., Budd, T., Kinshott, G., Mattinson, J., Mayhew, P., and Myhill, A. (2000) The 2000 British Crime Survey: England and Wales London: Home Office

McGee, C. (2000) Childhood Experiences of Domestic Violence London: Jessica Kingsley

Mama, A. (2000) 'Violence Against Black Women in the Home' in Hanmer, J. and Itzin, C. (eds) Home Truths About Domestic Violence London: Routledge 44-57

Mullender, A and Morley, R. (1994) Children Living with Domestic Violence London: Whiting and Birch

Mrazek, P.J., Lynch, M. A., and Bentovim, A. (1983) 'Sexual Abuse of Children in the United Kingdom' Child Abuse and Neglect 7 147-153..

National Institute for Clinical Evidence (2004) NICE Guideline on Self Harm London: NICE

National Institute for Clinical Evidence (2004) NICE Guideline on Posttraumatic Stress Disorder London: NICE 
Nurse, J. , Garcia-Morena, C., Phinney, A., Burchart, A., and Clarke, N. (2005) A Global Perspective on Adolescent Sexual Relationship Violence: A New Understanding for Health Outcomes and Opportunities for Prevention Geneva: World Health Organisation Office of the Deputy Prime Minister (2003) Supporting People London: ODPM

Office of the Deputy Prime Minister (2004) Mental Health and Social Exclusion London: SEU

Patel, P. (2000) 'Southall Black Sisters: Domestic Violence Campaigns and Alliances Across the Divisions of Race, Gender and Class' in Hanmer, J. and Itzin, C. (eds) Home Truths About Domestic Violence London: Routledge 167-185

Polusny, M.A. and Follette, V.M. (1995) 'Long Term Correlates of Child Sexual Abuse: Theory and Review of the Empirical Literature' Applied and Preventive Psychology 4 143-166

Richardson, J., Coid, J., Petruckevitch, A., Chung, W.S., Moorey, S,. and Feder, G. (2002) 'Identifying Domestic Violence: Cross Sectional Study in Primary Care' British Medical Journal 3242 February 274277

Skuse, D., Bentovim, A., Hodges, J., Stevenson, J., Andreou, C., Lanyado, M., New, M., Williams, B. and McMillan, D. (1998) 'Risk Factors for Development of Sexually Abusive Behaviour in Sexually Victimised Adolescent Boys: Cross Sectional Study' British Medical Journal 317 175-179

Ullman, S.E. and Brecklin, L.R. (2002) 'Sexual Assault History, PTSD and Mental Health Service Seeking in a National Sample of Women' Journal of Community Psychology 30 (3) 261-279

Walby, S. (2004) The Costs of Domestic Violence London: Department of Trade and Industry

Walby, S. and Allen, J. (2004) Inter-Personal Violence: Findings from the 2003 British Crime Survey London: Home Office

Widom, C.P. (1989) 'The Cycle of Violence' American Association for the Advancement of Science 244 160-166 

(DH) Department of Health

C C Crown copyright 2006

267992 1p $0.2 k$ Feb06 (FMP) 